\title{
Endotracheal Tubes: Old and New
}

\author{
Carl F Haas MLS RRT-ACCS FAARC, Richard M Eakin RRT-ACCS RN, \\ Mark A Konkle MPA RRT, and Ross Blank MD \\ Introduction \\ History and Early Development of the Endotracheal Tube \\ Anatomy of the Standard Endotracheal Tube \\ Specialty Tubes in the Operating Room \\ For Lung Isolation \\ For Use in Maintaining a Clear Facial Surgical Field \\ For Laser Surgery of the Airways \\ For Monitoring Laryngeal Nerve Integrity \\ Other Modifications \\ Endotracheal Tube Design to Minimize Cuff-Related Injury \\ Endotracheal Tube Design to Reduce Ventilator-Associated Pneumonia \\ Reducing the Impact of Microaspiration \\ Reducing the Formation and Presence of Biofilm \\ An ETT Bundle? \\ Summary
}

The development and evolution of the endotracheal tube (ETT) have been closely related to advances in surgery and anesthesia. Modifications were made to accomplish many tasks, including minimizing gross aspiration, isolating a lung, providing a clear facial surgical field during general anesthesia, monitoring laryngeal nerve damage during surgery, preventing airway fires during laser surgery, and administering medications. In critical care management, ventilator-associated pneumonia (VAP) is a major concern, as it is associated with increased morbidity, mortality, and cost. It is increasingly appreciated that the ETT itself is a primary causative risk for developing VAP. Unfortunately, contaminated oral and gastric secretions leak down past the inflated ETT cuff into the lung. Bacteria can also grow within the ETT in biofilm and re-enter the lung. Modifications to the ETT that attempt to prevent bacteria from entering around the ETT include maintaining an adequate cuff pressure against the tracheal wall, changing the material and shape of the cuff, and aspirating the secretions that sit above the cuff. Attempts to reduce bacterial entry through the tube include antimicrobial coating of the ETT and mechanically scraping the biofilm from within the ETT. Studies evaluating the effectiveness of these modifications and techniques demonstrate mixed results, and clear recommendations for which modification should be implemented are weak. Key words: endotracheal tube; double-lumen tube; bronchial blocker; RAE tube; laser-resistant tube; Parker Flex-Tip; Hunsaker Mon-Jet tube; biofilm; ventilator-associated pneumonia; subglottic secretion drainage; cuff pressure; microaspiration; polyurethane; tapered cuff; silver-coated endotracheal tube. [Respir Care 2014;59(6):933-955. (C) 2014 Daedalus Enterprises]

Mr Haas, Mr Eakin, and Mr Konkle are affiliated with Adult Respiratory Care, and Dr Blank is affiliated with the Department of Anesthesiology, University of Michigan Health System, Ann Arbor, Michigan.
Mr Haas presented a version of this paper at the 52nd ResPIRATORY CARE Journal Conference, "Adult Artificial Airways and Airway Adjuncts," held June 14 and 15, 2013, in St Petersburg, Florida. 


\section{ENDOTRACHEAL TUBES}

\section{Introduction}

Early descriptions of placing an artificial airway are primarily of emergencies, such as Andreas Vesalius (1543) placing a reed into the trachea of a pig to treat a pneumothorax ${ }^{1,2}$ or Benjamin Pugh (1754) performing the first endotracheal intubation to resuscitate a neonate with a leather covered coiled wire. ${ }^{1}$ However, the main evolution of the endotracheal tube (ETT) is intertwined with that of surgery and anesthesia and, more recently, with critical care medicine.

This paper will provide a brief history of some of the developments of the ETT before reviewing the anatomy of the current standard ETT. Following this will be a discussion highlighting special situations faced in the surgical suite and how ETTs are modified or redesigned to address these challenges. The last section describes how the ETT is evolving to address the problem of ventilator-associated pneumonia (VAP).

\section{History and Early Development of the Endotracheal Tube}

With the introduction of ether in the 1840s, undertaking surgical procedures became more common. General anesthesia was primarily provided through a device covering the patient's nose and mouth. The issue of gastric content aspiration was not generally appreciated, and postoperative pneumonia was a common problem. ${ }^{1}$ Trendelenburg (1869) is credited with designing the first inflatable cuff, which was a thin rubber bag fitted over the end of a tracheostomy tube, creating a tight seal to prevent aspiration during anesthesia. ${ }^{1,2}$ Preferring an alternative to tracheostomy, Macewen (1880) described relieving an obstruction by passing an oral tube into the trachea. ${ }^{2} \mathrm{He}$ was also the first to describe administering anesthesia (chloroform) via an orotracheal tube and used a metal tube with a sponge collar placed into the pharynx to prevent aspiration. ${ }^{3,4}$ Eisenmenger (1893) was the first to describe the use of a cuffed ETT, as well as the concept of a pilot balloon to monitor intracuff pressure. ${ }^{1,2,5}$

In the late 1800 s, another surgical challenge was that of preventing pulmonary collapse during thoracotomy. ${ }^{1}$ O'Dwyer (1887) introduced a variety of metal tubes that he placed in the larynx of patients with diphtheritic croup, thereby preventing the need for tracheostomy. ${ }^{3,6}$ These

\footnotetext{
The authors have disclosed no conflicts of interest.

Correspondence: Carl F Haas MLS RRT-ACCS FAARC, Adult Respiratory Care, UH B1-H230, 1500 E Medical Center Drive, University of Michigan Health System, Ann Arbor, MI 48109-0025. E-mail: chaas@umich.edu.
}

DOI: $10.4187 /$ respcare. 02868 tubes could also be attached to a bellows pump (Fell, 1888) to apply increased intratracheal pressure and help prevent pulmonary collapse during thoracic surgery. ${ }^{7}$ Anesthesiologist Franz Kuhn made significant contributions in the early $1900 \mathrm{~s} .6,8 \mathrm{He}$ also used metal tubes and preferred the oral route over tracheostomy and popularized orotracheal anesthesia. Kuhn was the first to stress the importance of the ETT as a route of removing pulmonary secretions. He published over 30 papers on orotracheal intubation and positive-pressure ventilation (PPV), wrote the first textbook on tracheal intubation in 1911, and helped develop the Kuhn-Dräger anesthesia machine for PPV. ${ }^{8}$

Placement of orotracheal tubes was primarily done blindly via digital manipulation until Jackson and Janeway (1913) published their experiences using laryngoscopy, paving the way for development and popularity of flexible rubber tubes. ${ }^{2}$ They used an anesthesia technique known as insufflation, in which gas was blown into the lungs via a small tube and exhaled gas flowed around the outside of the tube. Jackson introduced an improved laryngoscope (1920), making the endotracheal technique more accepted. Recognizing that the insufflation technique of anesthesia did not prevent aspiration, Rowbotham and Magill (1926) designed larger rubber tubes that allowed bidirectional gas flow through the tube. These tubes were sealed using pharyngeal sponges with hand-sewn gauze pull strings to help with removal. ${ }^{1,2,9}$ Although the detachable inflatable cuff had been introduced by Trendelenburg, it had fallen out of favor due to technical issues, and clinicians preferred to use pharyngeal packing with sponges to seal the upper airway. Guedel (1928) and Waters (1931) reintroduced the inflatable cuff to Magill's rubber tube and are credited with starting a period of ETT design. ${ }^{10}$ Their first cuffs were made from the fingers of rubber gloves and from rubber condoms. These cuffs, ranging from 3 to 4 inches long, were designed to sit half above and half below the glottis. ${ }^{11}$ Later, they designed cuffs from rubber dental dams that were shorter, 1.5 inches long, and designed to sit below the vocal cords. ${ }^{11}$

The polio epidemic in Europe (late 1950s) and the United States (early 1960s) demonstrated the value of cuffed endotracheal and tracheostomy tubes to apply PPV for respiratory failure. ${ }^{12}$ Reusable rubber ETTs and metal tracheostomy tubes with high-pressure low-volume rubber cuffs were the primary airways of the time. As polymer technology advanced, a disposable polyvinyl chloride (PVC) tube with a high-pressure low-volume cuff was introduced in 1968. ${ }^{13}$ Excessive cuff pressure reduces regional tracheal blood flow and is associated with lesions such as tracheomalacia, tracheal dilation, and stenosis, as well as tracheoesophageal fistula. These complications were increasingly being reported by the late 1960s as mechanical ventilation outside of the operating suite became more prominent. ${ }^{14-17}$ As the high-pressure low-volume cuff 


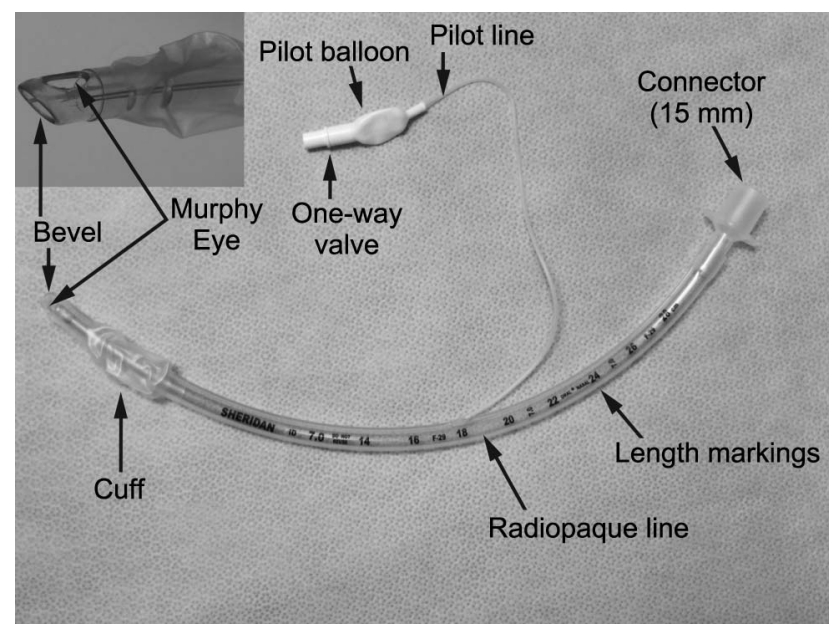

Fig. 1. Anatomy of the standard endotracheal tube.

became recognized as a problem, it became appreciated that increasing the size of the cuff and stretching the cuff material could result in an adequate seal at lower tracheal pressures. Some clinicians made their own high-volume low-pressure (HVLP) cuff by prestretching the cuff of the PVC tube using boiling water. ${ }^{18}$ Manufacturers introduced an HVLP PVC-cuffed ETT in the 1970s, which has become the standard ETT in use today. Desirable characteristics of PVC include that it is transparent, nontoxic, and inexpensive and conforms to the patient's anatomy at body temperature..$^{2,13}$

\section{Anatomy of the Standard Endotracheal Tube}

ETTs are generally made of PVC, although other materials include rubber, silicone, and metal. Most ETTs used in the operating room or critical care areas have standard design characteristics and features (Fig. 1). Markings along the length of the tube denote the number of centimeters from the tip of the tube, helping clinicians gauge initial insertion depth and monitor tube movement. Some tubes also have a mark to help guide proper depth of insertion such that the tube is placed under direct vision, with the vocal cords resting at a single marking or between doubleline markings on the tube surface. A radiopaque continuous marking imbedded in the length of the tube allows the distal tube tip to be identified on a chest radiograph to confirm appropriate depth of the tube.

The tip of the tube is designed with a slant or bevel facing to the left side at the tip of the tube. Because the tube is generally introduced on the right side of the standard left-handed laryngoscope, the left-sided bevel allows better visualization of the area ahead of the tube and easier passage through the vocal cords. Opposite the bevel, there is generally an additional side hole called the Murphy eye. Its purpose is to allow passage of gas and ventilation should the tip of the tube become obstructed, as may occur when up against the tracheal wall or with mucus plugging.

Most tubes have a cuff, an inflatable balloon near the end of the tube that surrounds its circumference and forms a seal against the wall of the trachea. The cuff helps prevent secretions and fluid from leaking down into the trachea and lungs and gas from leaking around it during PPV. The cuff is attached to a smaller inflatable balloon via a hollow catheter called the pilot line. The balloon, referred to as the pilot balloon, resides outside the patient and acts as a tactile gauge of cuff pressure, as well as a small reservoir to help reduce minor changes in intracuff pressure. A one-way valve attached to the pilot balloon prevents gas from escaping the cuff and provides a connector to attach a syringe or pressure-monitoring device.

All tubes have a standard adapter that allows a variety of respiratory or anesthesia equipment to be attached to the tube. The connector at one end has a standardized external diameter of $15 \mathrm{~mm}$ to attach to equipment and the other end sized to snugly pressure-fit into the tube.

\section{Specialty Tubes in the Operating Room}

As noted earlier, many of the evolutionary modifications made to the ETT have been to address particular problems encountered in the operating room. The following section describes a few of these specialty designs.

\section{For Lung Isolation}

An issue during thoracic surgery in the early 1900s was that of transbronchial spillover and difficulties ventilating in situations of air leak (eg, valvular pneumothorax, bronchial fistula, tension cyst). ${ }^{1}$ Gale and Waters (1932) described an ETT used for anesthesia made of rubber that could be molded in hot water to form a bend in the tip and placed into a main bronchus. ${ }^{1,6}$ Magill (1936) designed right-sided and left-sided endobronchial tubes with cuffs. ${ }^{1}$ Carlens (1949) designed a double-lumen tube (DLT) for spirometric studies, but Bjork used it during thoracic surgery to prevent spillage of contaminated secretions from one lung into the other. ${ }^{1,2,6,19}$ Their tube contained a carinal hook to help properly position the left-sided endobronchial tube (Fig. 2). Robertshaw (1962) introduced a modified red rubber DLT with right-sided and left-sided versions and a larger internal diameter but without a carinal hook (Fig. 3).2,20 Newer DLT models are similar to the Robertshaw tube except they are made of PVC, have HVLP cuffs, and contain radiopaque markers. ${ }^{20}$

The sidedness of modern DLTs refers to the longer endobronchial lumen. The other tracheal lumen ends in the distal trachea and is used to ventilate the contralateral lung. Thus, either left-sided or right-sided DLTs can be used to isolate either lung. Left-sided DLTs are more com- 


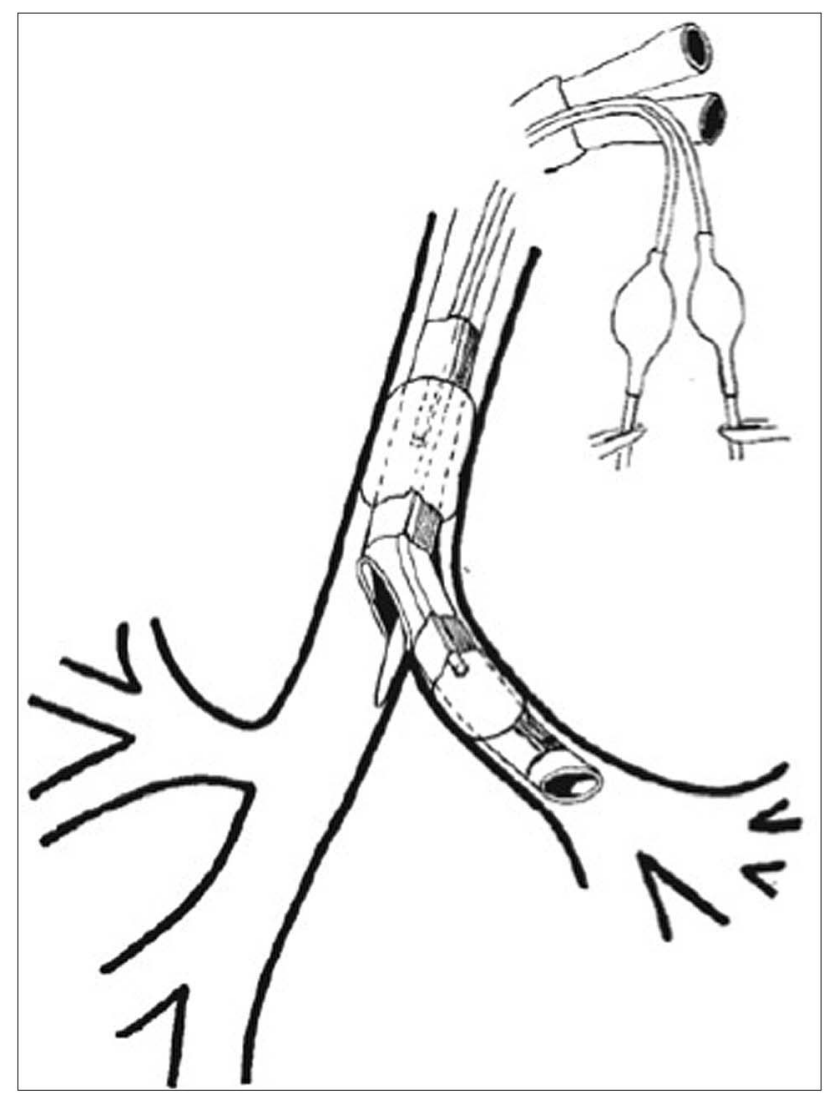

Fig. 2. Original description of the Carlens double-lumen tube. Note the carinal hook to aid in proper placement. From Reference 19, with permission.

monly used due to the relative long length of the left main bronchus. Right-sided DLTs have a side hole that must be aligned with the takeoff of the right upper lobe bronchus. They may be necessary when surgery involves the left main bronchus (left pneumonectomy, left-sided sleeve resection) or if the left main bronchus is stenotic or compressed and cannot accommodate the endobronchial tube. Absolute indications for lung isolation in the operating room include the prevention of unilateral blood or pus from contaminating the contralateral lung, inability to ventilate one lung due to a large bronchopleural fistula or tracheobronchial disruption, whole lung lavage for pulmonary alveolar proteinosis, or need for differential lung ventilation in settings of asymmetric respiratory failure. Much more commonly, lung isolation is employed to facilitate surgical exposure for lung resections and other operations via thoracotomy, such as cardiac, esophageal, and anterior thoracic spine surgeries. Lung isolation is particularly crucial to maximize visualization during minimally invasive video-assisted thoracoscopic surgical procedures.

An alternative method of isolating the lung is a bronchial blocker, which is a balloon-tipped catheter that is passed through a standard ETT into the desired lung bron-

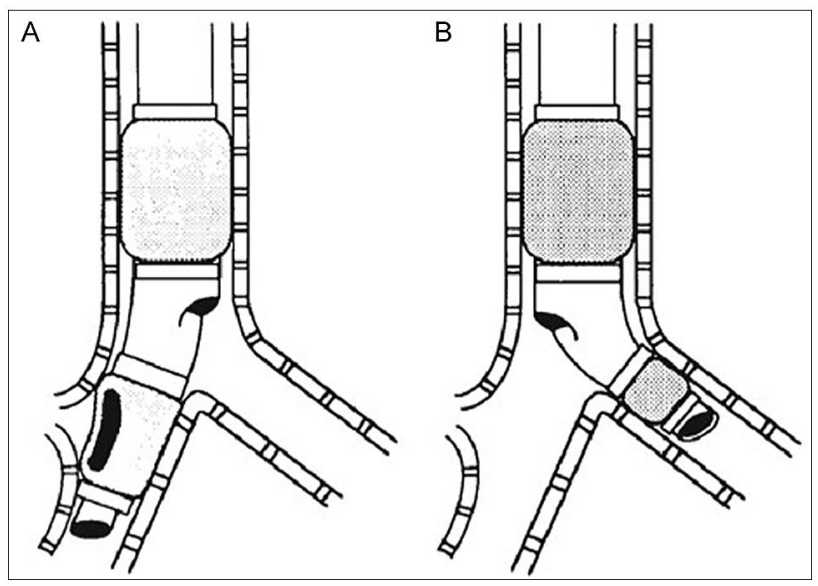

Fig. 3. Placement of the right-sided (A) and left-sided (B) Robertshaw double-lumen tubes. Note the slotted endobronchial cuff in the right double-lumen tube $(A)$ for right upper lobe ventilation. From Reference 20, with permission.

chus. ${ }^{21,22}$ The blocker is a hollow tube, and once the balloon is inflated and the lung tissue distal to the balloon is isolated, suction can be applied to facilitate lung collapse. An advantage of the bronchial blocker is that this method does not require a DLT to be placed for the procedure or replaced following the procedure should ongoing mechanical ventilation be required. Common bronchial blockers include the Arndt wire-guided (Cook Critical Care, Bloomington, Indiana), the Cohen tip-deflecting (Cook Critical Care), the Fuji Uniblocker (Fuji Corp, Tokyo, Japan), and the double-balloon Rusch EZ-Blocker (Teleflex Medical, Research Triangle Park, North Carolina). These differ from each other in how the blocker is directed into left versus right main bronchi. All require fiberoptic guidance to confirm proper placement. The Univent ETT (Fuji Corp) contains a bronchial blocker, with a built-in curved tip resembling a hockey stick, in a channel parallel to the main lumen. ${ }^{23}$

The Papworth BiVent ETT (P3 Medical, Bristol, United Kingdom) is a new ETT to use with bronchial blockers. ${ }^{24}$ It has 2 side-by-side D-shaped lumens and a distal pliable tip that forks and sits on the carina. The blocker is then advanced down the lumen directed to the lung desiring isolation. ${ }^{25}$ The inventor has described initial clinical experience with the device, but no clinical studies have been reported. ${ }^{26}$

\section{For Use in Maintaining a Clear Facial Surgical Field}

Named after the 3 inventors Ring, Adair, and Elwyn, the RAE ETT was introduced in the 1970s. It is a preshaped orotracheal or nasotracheal tube designed to keep the ETT and breathing circuit away from the surgical field. ${ }^{27}$ The tubes are prebent to reduce the likelihood of kinking in the process of clearing tubing from the surgical field. 


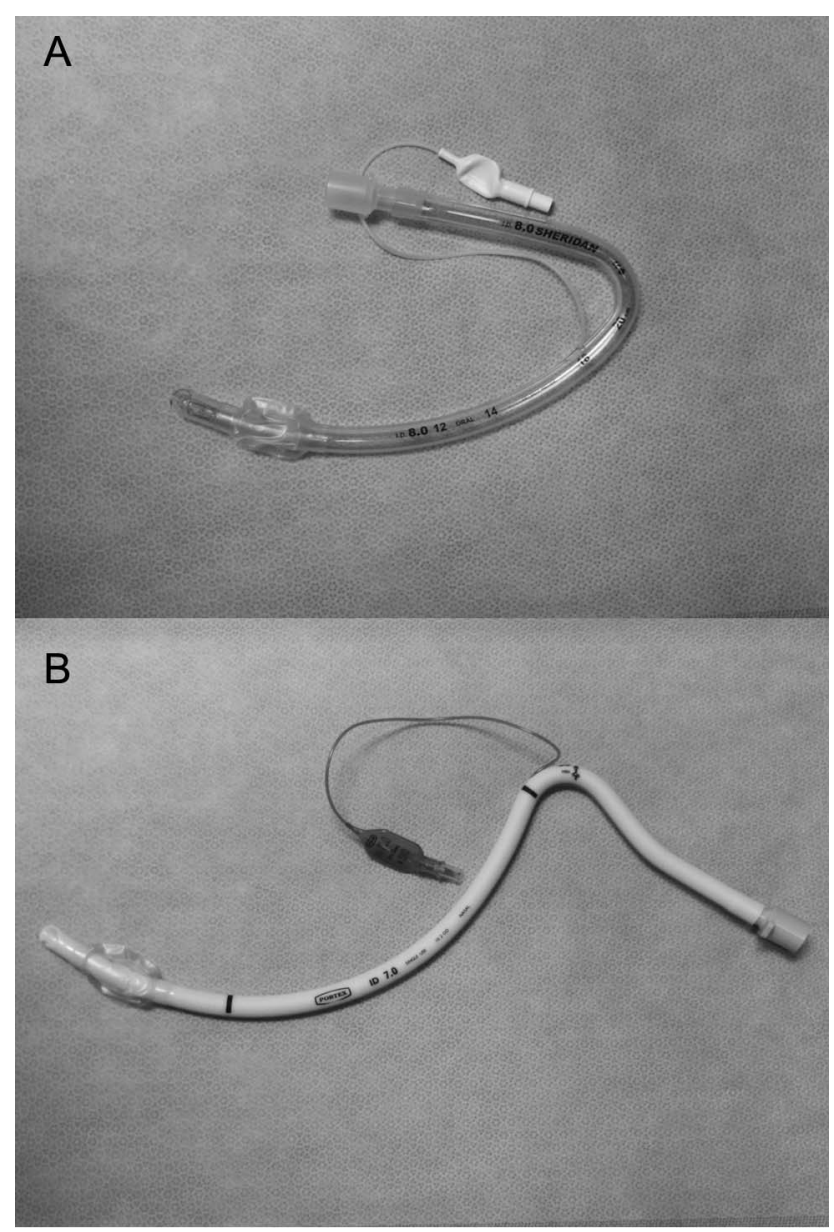

Fig. 4. RAE (Ring-Adair-Elwyn) endotracheal tubes. A: south-facing oral tube. B: north-facing nasal tube.

The orotracheal RAE tube has a preshaped form that curls under the chin to allow surgical access to the upper face for ophthalmic, otolaryngology, and other facial surgeries (Fig. 4A). The nasotracheal RAE tube is preformed to place the bend outside of the nares, allowing the tube to lie over the forehead (Fig. 4B). This allows for an unobstructed surgical field for facial-oral surgery, dental procedures, and oropharyngeal surgeries.

\section{For Laser Surgery of the Airways}

Laser surgery has gained wide popularity for management of airway and lung masses since Strong and Jako reported their experience in $1972 .{ }^{28}$ The 4 most common types of laser systems used in cancer treatment include the carbon dioxide, neodymium:yttrium aluminum garnet, potassium titanyl phosphate, and argon lasers, although others have been described. ${ }^{29}$ The procedure is considered to be relatively safe, but due to the extreme focused heat generated by the laser beam, caution and preventive measures must be taken in the operating suite to protect the patient and health care workers from inadvertent fires. ${ }^{30} \mathrm{In}$ particular, fires involving the ETT have been reported using the neodymium:yttrium aluminum garnet $^{31,32}$ and carbon dioxide ${ }^{33-35}$ lasers, as well as the new diode laser. $^{36}$

Investigators have studied the incendiary characteristics of various ETT materials. ${ }^{34,37-39}$ The standard red rubber and PVC tubes readily ignite, particularly at high $\mathrm{F}_{\mathrm{IO}_{2}}$ and in the presence of $\mathrm{N}_{2} \mathrm{O}$, but resist ignition when wrapped with copper or aluminum foil. As expected, the specially designed laser-resistant tubes perform the best. As of 2010, the 4 laser-resistant tubes available were the Xomed Laser-Shield II (Medtronic ENT, Jacksonville, Florida), the Sheridan Laser-Trach ETT (Teleflex Medical), the Rusch Lasertubus ETT (Teleflex Medical), and the Mallinckrodt Laser-Flex (Covidien, Mansfield, Massachusetts). ${ }^{29}$

Safety precautions to reduce the likelihood of triggering an ETT-related fire include limiting the laser output to the lowest clinically acceptable power intensity and pulse duration, using the lowest possible $\mathrm{F}_{\mathrm{IO}_{2}}(\leq 0.30$, if tolerated) without nitrous oxide (which supports combustion) during laser firing, and using a laser-resistant tracheal tube. ${ }^{40-42} \mathrm{It}$ is suggested that the ETT cuff be filled with blue-dyed saline in place of air to act as a heat sink and help prevent cuff ignition. In the event of a fire, this fluid might extinguish flames, and the dye would help provide a visual indication of cuff rupture. ${ }^{29}$ The Laser-Flex tube uses a double-cuff system. If one cuff bursts from the laser, the second is still working, allowing ventilation and preventing aspiration and, more importantly, leaking of ventilation gases with oxygen into the flaming field.

\section{For Monitoring Laryngeal Nerve Integrity}

Intraoperative neuromonitoring of the recurrent laryngeal nerve has gained acceptance during thyroid surgeries and other surgeries of the neck and base of the skull that might result in injury of the recurrent laryngeal or vagus nerves. ${ }^{43-46}$ The anatomic proximity of the recurrent laryngeal nerve to the vocal cords allows sensors to be adhered to or embedded on an ETT and positioned to continuously monitor vocal cord electromyogram activity during surgery. ${ }^{47}$ The NIM electromyography ETT (Xomed, Medtronic ENT) is shown in Figure 5. The blue markings help with proper placement at the level of the vocal cords, but attention to monitoring of the signal must be maintained, as the position of the tube and sensors can move when the head is flexed. ${ }^{43}$ As the ETT is slightly larger in diameter than a conventional ETT, it may be more difficult to place via direct laryngoscopy, and video laryngoscopy may be of assistance. ${ }^{49}$ The nerve integrity monitor ETT is a silicone-based tube with a special silicone elastomer cuff to allow better tracheal conformity and to reduce tracheal 


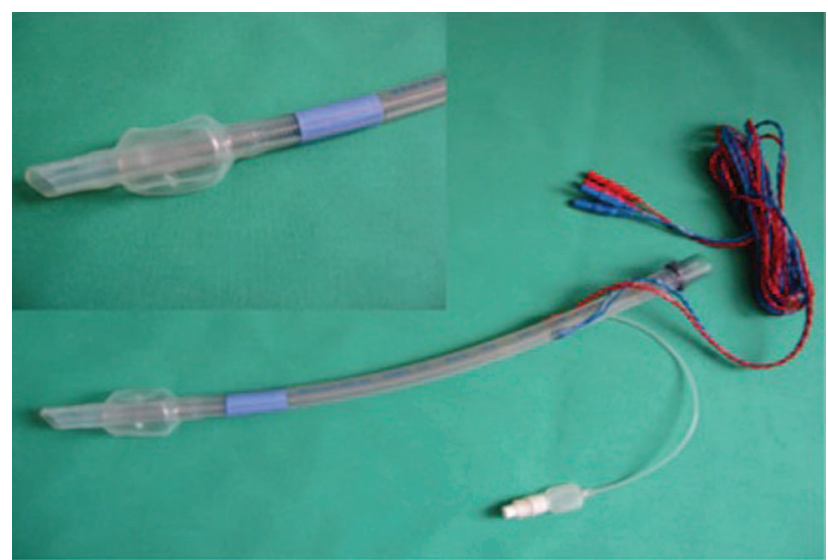

Fig. 5. Nerve integrity monitoring endotracheal tube. From Reference 48 , with permission.

tissue trauma. A recent report describes cuff herniation and subsequent airway obstruction and pneumothorax with this type of tube, ${ }^{50}$ although these complications appear to be rare.

\section{Other Modifications}

Parker Flex-Tip. Orotracheal and nasotracheal fiberoptic intubation generally involves placing a fiberoptic bronchoscope into the trachea and then blindly advancing a preloaded ETT over the scope. This method has been associated with complications and challenges related to the design of the standard ETT, particularly tissue trauma and inability to redirect and pass by anatomic structures..$^{51,52}$ To help address this, the Parker Flex-Tip tube (Parker Medical, Englewood, Colorado) has a soft, flexible, hemispherical, curved tip pointing toward the center of the distal lumen of the tube, rather than the straight, stiff, right-sided tip of the standard ETT (Fig. 6). The curved tip hugs fiberoptic scopes (as well as bougies and exchange catheters) more tightly than other tubes, and it has been associated with a greater incidence of initial success and faster tube passage than a standard ETT. ${ }^{53}$ During nasotracheal intubation, the Parker Flex-Tip has been associated with less tissue trauma, bleeding, and nose pain, ${ }^{54,55}$ as long as its bevel and tip do not face or contact the turbinates or septum. ${ }^{52}$ Case reports associate the Parker Flex-Tip with less subglottic impingement on the tracheal wall during nasotracheal intubation ${ }^{56}$ and easier passage over a bougie tube exchanger. ${ }^{57}$

Reinforced Tubes. Wire-reinforced or armored ETTs incorporate a series of concentric steel wire rings embedded in the wall of the tube along its entire length. These are designed to make the tube flexible and resist kinking with positioning. They are promoted for use in head and neck
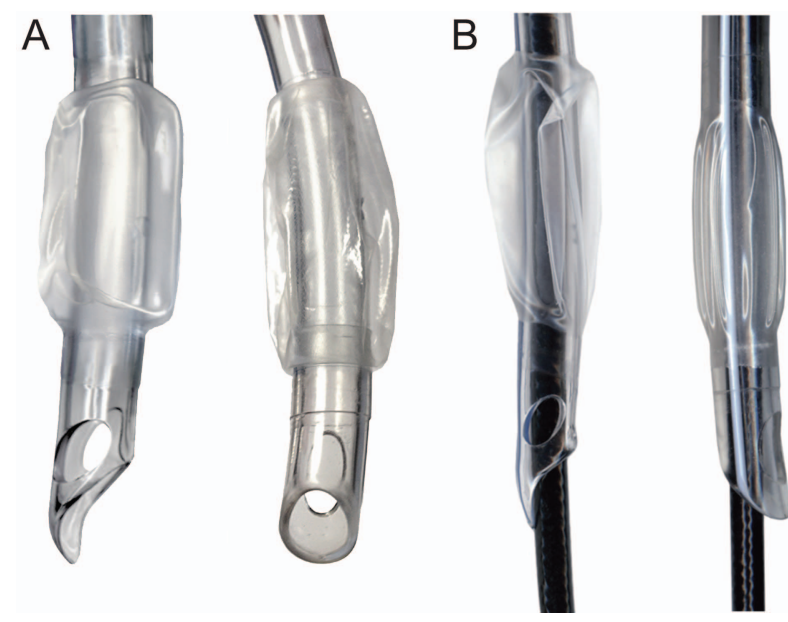

Fig. 6. A: The Parker Flex-Tip tube (left) has a flexible tip pointing toward the center of the distal lumen. The standard tube is seen at right. B: The Parker Flex-Tip tube (left) leaves a smaller gap between the tube and the fiberscope than the standard tube (right) with the same internal diameter. Courtesy Parker Medical.

surgery, where surgical positioning may require bending and movement of the ETT. They are also useful for intubating through a mature tracheostomy stoma or a surgically divided airway (as in tracheal reconstruction), where the flexibility of the tube allows less interference with the surgical field. Although kink-resistant, these tubes are not kink- or obstruction-proof. ${ }^{58-61}$ Unfortunately, if the tube is crimped or kinked, it cannot return to its normal shape and must be changed.

Hunsaker Mon-Jet Tube. Introduced in 1994, the Hunsaker Mon-Jet ETT is a narrow laser-compatible tube designed to facilitate exposure during airway surgery while providing a channel for subglottic high-frequency jet ventilation to support gas exchange. ${ }^{62,63}$ With an outer diameter of $4.3 \mathrm{~mm}$, it has a considerably lower profile than a conventional adult ETT (Fig. 7). The distal tip is surrounded by a plastic cage that helps to maintain the lumen tip in the center of the airway and not against the mucosa. The Hunsaker Mon-Jet ETT also contains an additional channel for measuring airway pressure or carbon dioxide levels. Complications are reported to be $<6 \%$ and are primarily related to hypoxia and hypercarbia associated with jet ventilation. ${ }^{64,65}$ Due to the open cuffless design, it is not capable of delivering anesthetic gases without contaminating the environment and requires the use of total intravenous anesthesia.

LITA Endotracheal Tube. A tube designed for laryngotracheal instillation of topical anesthetic, the LITA ETT contains a separate channel for injection of topical anesthetic via 8 holes above and 2 holes below the cuff. Administration of local anesthetic to the larynx and trachea is 


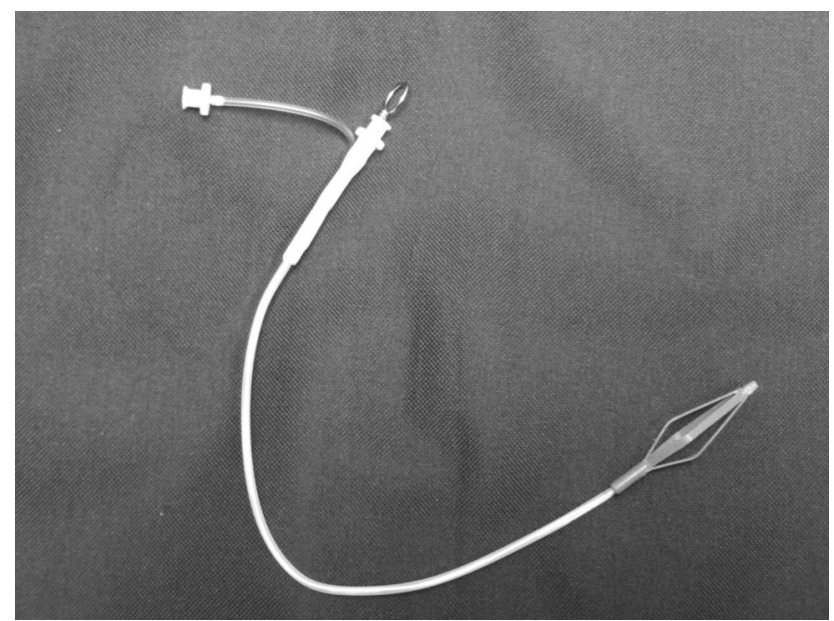

Fig. 7. Hunsaker Mon-Jet endotracheal tube.

intended to decrease airway irritability, coughing, and possibly laryngospasm during emergence from anesthesia. ${ }^{66,67}$ Alternatives include direct application of local anesthetic to the larynx at the time of laryngoscopy and filling the cuff of a normal ETT with a local anesthetic solution.

\section{Endotracheal Tube Design to Minimize Cuff-Related Injury}

High-pressure low-volume cuffs were associated with tracheal injury, and the introduction of the HVLP cuff was thought to minimize this complication by applying a safe pressure over a larger surface area. Indeed, the frequency of reports of complications lessened following the introduction of the HVLP cuff. ${ }^{13}$

Two modifications of the standard ETT were introduced commercially in the 1970s. One modification was to replace the standard pilot balloon with a larger balloon containing an inner pressure-regulating valve that maintains intracuff pressure at $\sim 30 \mathrm{~cm} \mathrm{H}_{2} \mathrm{O}$ (Fig. 8). ${ }^{68}$ Studies suggest that this system, referred to as a Lanz valve, maintains a safe pressure and may be associated with reduced tracheal injury. ${ }^{69,70}$ The tube is still available (Mallinckrodt, Neunkirchen-Seelscheid, Germany) but is not routinely used, possibly due to increased cost, the introduction of other HVLP cuff designs, and interference with the selfsealing characteristics of the cuff. With the standard cuff, during the inspiratory phase of PPV, the increased airway pressure compresses the distal end of the cuff, causing an increase in intracuff pressure and a bulging of the proximal end, thereby allowing a good seal in spite of higher ventilating pressures compared with intracuff pressures during exhalation. Systems allowing automatic rapid reduction of increasing cuff pressure, such as the Lanz system, have been shown to overcompensate and possibly allow microaspiration. ${ }^{71,72}$

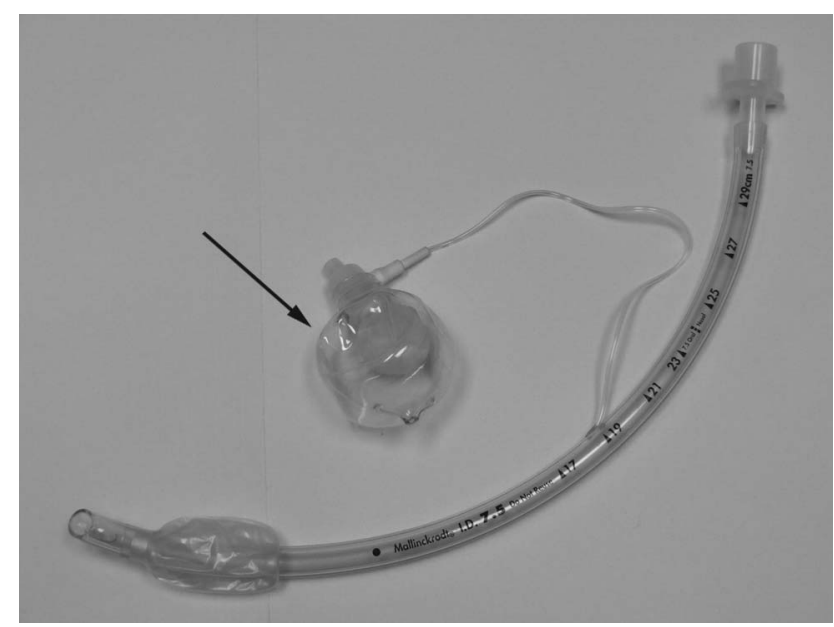

Fig. 8. A high-volume low-pressure endotracheal tube with a Lanz pressure-regulating valve (arrow).

Another modification was to replace the air-filled cuff with a self-inflating foam cuff. Reported by Kamen and Wilkinson in 1971, it is known as the Bivona Fome-Cuf tube (Smiths Medical, Dublin, Ohio). It has been shown to exert low tracheal wall pressures ${ }^{73,74}$ but requires an adapter to allow pressurization during PPV with elevated pressures to prevent gross leakage. The cuff was initially used with ETTs and tracheostomies, but it is currently available primarily on tracheostomy tubes.

There have been several reports of novel cuff designs attempting to improve the seal at low tracheal wall pressure. The parachute cuff had holes in the distal part of the cuff wall, allowing synchronous inflation during positivepressure breathing. Early versions had technical issues with proper inflation and inadequate protection from aspiration. ${ }^{75-77}$ Nordin and Lyttkens (1979) reported using PEEP to maintain inflation of the cuff and demonstrated adequate protection in an animal model, ${ }^{77}$ but this concept did not progress.

Reali-Forster et al ${ }^{78}$ described a prototype ETT (1996) with several major differences from the standard ETT: (1) the wall of the tube was thinner $(0.2$ vs $1.6 \mathrm{~mm}$ for standard ETT) to reduce resistance (by 3-5-fold in adults), (2) the tracheal cuff was replaced with a sealing system made of 12-20 doughnut-shaped thin layers of polyurethane film (gills), (3) the gill portion rested within the glottis and (4) the oropharyngeal section of the ETT was reinforced with wire to prevent kinking. This tube was compared with a standard PVC ETT in a sheep ventilated for $3 \mathrm{~d}$. The prototype ETT prevented fluid leakage down past its cuff better than the standard cuff, and there were no histologic differences in the trachea or laryngeal areas. It was later shown to be associated with less reduction in tracheal mucus flow compared with the standard cuffed tube. ${ }^{79}$ Clinical trials have not been reported on this tube. 


\section{Endotracheal Tube Design to Reduce Ventilator-Associated Pneumonia}

VAP is the most common nosocomial infection of mechanically ventilated patients in the ICU and is associated with significant morbidity, mortality, and health care cost. ${ }^{80-84}$ ETTs are increasingly implicated as the major causative risk factor for VAP, suggesting that the condition be referred to as endotracheal tube-associated pneumonia rather than VAP. ${ }^{85,86}$

VAP is caused by microorganisms entering the lung. Placement of an ETT increases the likelihood of pathogens entering the lower airways in several ways. The intubation process itself may introduce bacteria via contamination of the tube and aspiration of gastric content. ${ }^{87,88}$ More importantly, the presence of a tube between the vocal cords presents a direct passage for microorganisms into the lower airways and lungs. As such, the ETT inhibits normal glottic closure to prevent aspiration and impairs other protective mechanisms such as cough and mucus clearance. ${ }^{85,89}$ Aspirated fluid and oral secretions entering the lower airway through the open glottis sit above the inflated ETT cuff and then leak past the cuff despite modest cuff inflation pressure. ${ }^{90-95}$ Bacteria can also accumulate on the interior of the ETT, creating a biofilm that can be dislodged and reintroduced into the lung. ${ }^{96,97}$ Significant effort is being placed on redesigning the ETT to reduce the incidence of VAP. ${ }^{11,86,98-101}$ Efforts can be categorized as those that might reduce microaspiration and those that might reduce biofilm, in essence preventing bacteria from entering around the tube or through it. ${ }^{99,100}$

\section{Reducing the Impact of Microaspiration}

Design efforts in this area have focused primarily on blocking leakage of subglottic secretions and reducing the volume and virulence of these secretions.

Cuff Pressure. A common practice to provide a safe inflation pressure is to inflate the cuff either until just a minimal leak occurs at peak inspiration or with slightly more volume to fully occlude the airway and prevent a leak during PPV. ${ }^{102-104}$ These techniques, referred to as the minimum leak technique and minimum occlusive volume, respectively, focus on maintaining a safe maximum pressure to minimize tracheal injury, but they do not address providing a minimum pressure to prevent fluid leakage and may increase the risk for VAP. ${ }^{105}$ Moreover, neither technique ensures a safe maximum pressure, particularly with high ventilating pressures. ${ }^{106,107}$ It is recommended that cuff pressure be measured directly and maintained at 20-30 $\mathrm{cm} \mathrm{H}_{2} \mathrm{O}$. $86,87,108$ Rello et al ${ }^{88}$ demonstrated that a cuff pressure $<20 \mathrm{~cm} \mathrm{H}_{2} \mathrm{O}$ during the first $8 \mathrm{~d}$ of intubation was an independent risk factor for developing VAP (relative risk 4.23, 95\% CI 1.12-15.92). Conversely, a pressure $>30 \mathrm{~cm} \mathrm{H}_{2} \mathrm{O}$ may compromise local blood flow and lead to tissue injury. ${ }^{70}$

Systems that automatically control tracheal cuff inflation pressure maintain a more consistent pressure, but their impact on preventing VAP is mixed. Valencia et al ${ }^{109}$ randomized 142 subjects to cuff inflation by either an automated device or manual pressure measurement every $8 \mathrm{~h}$. They found a higher rate of measurement to be within the recommended range of $20-30 \mathrm{~cm} \mathrm{H}_{2} \mathrm{O}$ in the automated group (79.3\% vs $48.3 \%$ ). Fewer measurements were $<20 \mathrm{~cm} \mathrm{H}_{2} \mathrm{O}$ in the automated group $(0.7 \%$ vs $45.3 \%)$, whereas, surprisingly, there was also a higher rate of measurement $>30 \mathrm{~cm} \mathrm{H}_{2} \mathrm{O}(20.0 \%$ vs $6.4 \%)$. There was no difference in VAP rate between groups. A more recent study by Nseir et al ${ }^{110}$ randomized 122 subjects to an automated system or to manual measurements 3 times daily. The automated system was associated with greater ability to keep pressure within the range of $20-30 \mathrm{~cm} \mathrm{H}_{2} \mathrm{O}(98 \%$ vs $74 \%)$, fewer measurements $<20 \mathrm{~cm} \mathrm{H}_{2} \mathrm{O}(0.1 \%$ vs $19 \%)$ or $>30 \mathrm{~cm} \mathrm{H}_{2} \mathrm{O}(0.7 \%$ vs $5 \%)$, and a lower VAP rate $(9.8$ vs $26.2 \%, P=.032) .{ }^{110}$

Cuff Material. The standard HVLP PVC cuff is designed to inflate to $1.5-2$ times the size of the normal trachea. ${ }^{70} \mathrm{In}$ doing so, the cuff presumably will conform to the tracheal wall size, provide an air seal during inspiration, and prevent gross fluid leakage during expiration at safe tracheal wall pressures. Unfortunately, longitudinal folds are created when this type of cuff inflates, and microaspiration occurs down through these channels. ${ }^{111}$ The search to find a solution to prevent the cuff folds has led to design changes in both the cuff material and the cuff shape.

PVC cuff material is $\sim 50 \mu \mathrm{m}$ thick, and a thinner material may produce fewer folds or folds with smaller channels, reducing leakage. One of the first material changes to be studied was polyurethane, which is considerably thinner $(\sim 7 \mu \mathrm{m})$ than PVC. Polyurethane may provide an adequate seal to prevent air leakage at a lower cuff pressure than $\mathrm{PVC}^{112}$ and has consistently been shown to allow less fluid leakage than PVC cuffs in bench studies. ${ }^{113-115}$ Clinical studies suggest that polyurethane may be associated with a reduced VAP rate. A randomized trial compared a PVC-cuffed tube with a tube that had both a polyurethane cuff and a subglottic secretion drainage (SSD) system. ${ }^{116}$ The polyurethane-cuffed SSD tube was associated with a lower VAP rate $(7.9 \%$ vs $22.1 \%, P=.001)$, but it is unclear whether the polyurethane or the SSD system was the contributing factor. Poelaert et al ${ }^{117}$ randomized 134 subjects undergoing cardiac surgery to intubation with an ETT with either a polyurethane or PVC cuff. The polyurethane group showed fewer early postoperative pneumonias (23\% vs $42 \%, P=.02)$ and less antibiotic use. Miller et al ${ }^{118}$ conducted a before and after 
study in which a PVC-cuffed ETT was used during the 12-month period before using a polyurethane-cuffed ETT. The VAP rate was lower during the period with the polyurethane tube ( 2.8 vs $5.3 / 1,000$ ventilator days, $P=.014$ ), although when switched back to the PVC tube following the study, the VAP rate increased to only 3.5/1,000 ventilator days. Although polyurethane appears to help reduce leakage compared with PVC and may be associated with lower VAP rates, a recent study showed that it does not absolutely prevent microaspiration. Bulpa et $\mathrm{al}^{119}$ randomized 29 subjects to PVC-cuffed or polyurethane-cuffed ETTs. A radioactive saline solution was instilled into the subglottic space and monitored for $12 \mathrm{~h}$. Overall, 38\% of the subjects had evidence of aspiration of the subglottic fluid: there was a nonsignificant difference between the PVC (46\%) and polyurethane (31\%) groups.

Prototypes using other cuff materials have been described. Zanella et al ${ }^{120}$ reported a double-layer cuff in which a standard HVLP PVC cuff was draped with a highly compliant cuff made of a natural latex rubber with $0.5 \mathrm{~mL}$ of gel between the cuff layers. As the PVC cuff inflated, it stretched the easily distended latex cuff, which did not create folds and provided adequate seal. This type of cuff has been shown in bench studies to prevent leakage better than those on PVC-cuffed and polyurethane-cuffed ETTs. ${ }^{115,120}$ Interestingly, their study comparing the prototype to combinations of tubes with polyurethane versus PVC material and cylindrical versus tapered shapes showed that $\mathrm{PEEP} \geq 5 \mathrm{~cm} \mathrm{H}_{2} \mathrm{O}$ was sufficient to prevent most leakage in the polyurethane-cuffed tubes regardless of shape (Fig. 9). ${ }^{115}$ PEEP levels of $10-15 \mathrm{~cm} \mathrm{H}_{2} \mathrm{O}$ were required to prevent leakage around the PVC-cuffed tubes. This beneficial effect of PEEP on leakage around the cuff has been confirmed by others. ${ }^{121,122}$

Kolobow et al ${ }^{123}$ described a prototype that replaced the PVC cuff with a thin walled cuff made of Lycra polyurethane. In a bench study of fluid leakage, the prototype did not allow any water to leak over a 24-h period, whereas the average leak rate for a polyurethane cuff was $1.2 \pm 0.4 \mathrm{~mL} / \mathrm{h}$, and that for a PVC cuff was $1,182 \pm 1,321 \mathrm{~mL} / \mathrm{h}^{123}$

Cuff Shape. Because the cylindrical HVLP cuff forms folds when inflated, a tapered cuff shape was designed in an attempt to reduce leakage past the cuff by creating a zone of sealing. At the top of the cuff, where the diameter is larger, there may be folds, but as the cuff diameter narrows, there will be a point at which the outer cuff diameter corresponds to the internal tracheal diameter, and no cuff folding occurs (Fig. 10). ${ }^{114}$ Bench studies have shown this shape to be superior to the standard cylindrical cuff in reducing leakage, but it may not offer an advantage over that gained from using polyurethane. ${ }^{114,115,124-126}$
Dave et al ${ }^{114}$ evaluated fluid leakage and compared a polyurethane-tapered cuff with 2 other polyurethane cylindrical cuffs and 3 PVC cylindrical cuffs in 3 simulated adult tracheal sizes $(16,20$, and $22 \mathrm{~mm})$ using $7.5-\mathrm{mm}$ ETTs. The polyurethane tapered cuff was found to be as effective as the polyurethane cylindrical cuff in the smaller tracheal size but more effective in preventing leakage in the larger tracheal size. This could be because the polyurethane cylindrical cuff studied (Microcuff, KimberlyClark, Irving, Texas) had a smaller outer diameter (22 mm) than the standard cylindrical cuffs $(\sim 26-30 \mathrm{~mm})$ or the tapered cuff ( $27 \mathrm{~mm}$ at the proximal end, $20 \mathrm{~mm}$ at the distal end). The authors also confirmed that the PVC cuffs allowed more leakage than the polyurethane cuffs.

Shiotsuka et al ${ }^{124}$ evaluated 5 PVC-cuffed 8.0-mm ETTs in a bench model. One had a tapered shape, and the others were cylindrical. The tapered cuff allowed significantly less fluid leakage than the cylindrical cuffs. In another study, Madjdpour et al ${ }^{125}$ evaluated the air-sealing characteristics of 4 ETTs from the same manufacturer in a bench model. Combinations of cuff pressure and ventilator peak inspiratory pressures were applied to tubes with the following cuff characteristics: polyurethane tapered, polyurethane cylindrical, PVC tapered, and PVC cylindrical. The authors concluded that a tapered cuff improved airsealing ability of PVC-cuffed ETTs, polyurethane allowed less air leakage than PVC regardless of shape, and the tapered shape did not result in a significant reduction in air leakage beyond that gained from the polyurethane cuff. ${ }^{125}$

Most recently, Li Bassi et al ${ }^{126}$ conducted a study to determine the association of fluid leakage with the cuff's features: outer diameter, length, material, shape, compliance, and internal pressure. They studied 8 tubes: 2 with PVC cylinder-shaped cuffs, 3 with PVC tapered cuffs, and one each of polyurethane cylindrical and polyurethane tapered cuffs. The ratio of cuff outer diameter to length was calculated, and the pressure applied to the simulated tracheal wall by the cuff was measured. The main findings suggested that the internal cuff pressure, the cuff outer diameter, the cuff material, and the cuff length are the primary determinants of fluid leakage. Polyurethane cuffs performed better than the PVC cuffs, regardless of shape. Comparing ratios of cuff outer diameter to length, tubes with a ratio of $<0.60$ performed better than those with a ratio of $>0.85$. It was noted that both polyurethane cuffs had a low ratio (longer and narrower) compared with those tubes that allowed significant leakage. Although the authors warned against concluding that the material (polyurethane) was the main factor in reducing leakage rather than the dimension of the cuff, they noted that the polyurethane tapered SealGuard (Covidien) performed better than the PVC tapered TaperGuard (Covidien) despite both having identical design dimensions. ${ }^{126}$ 

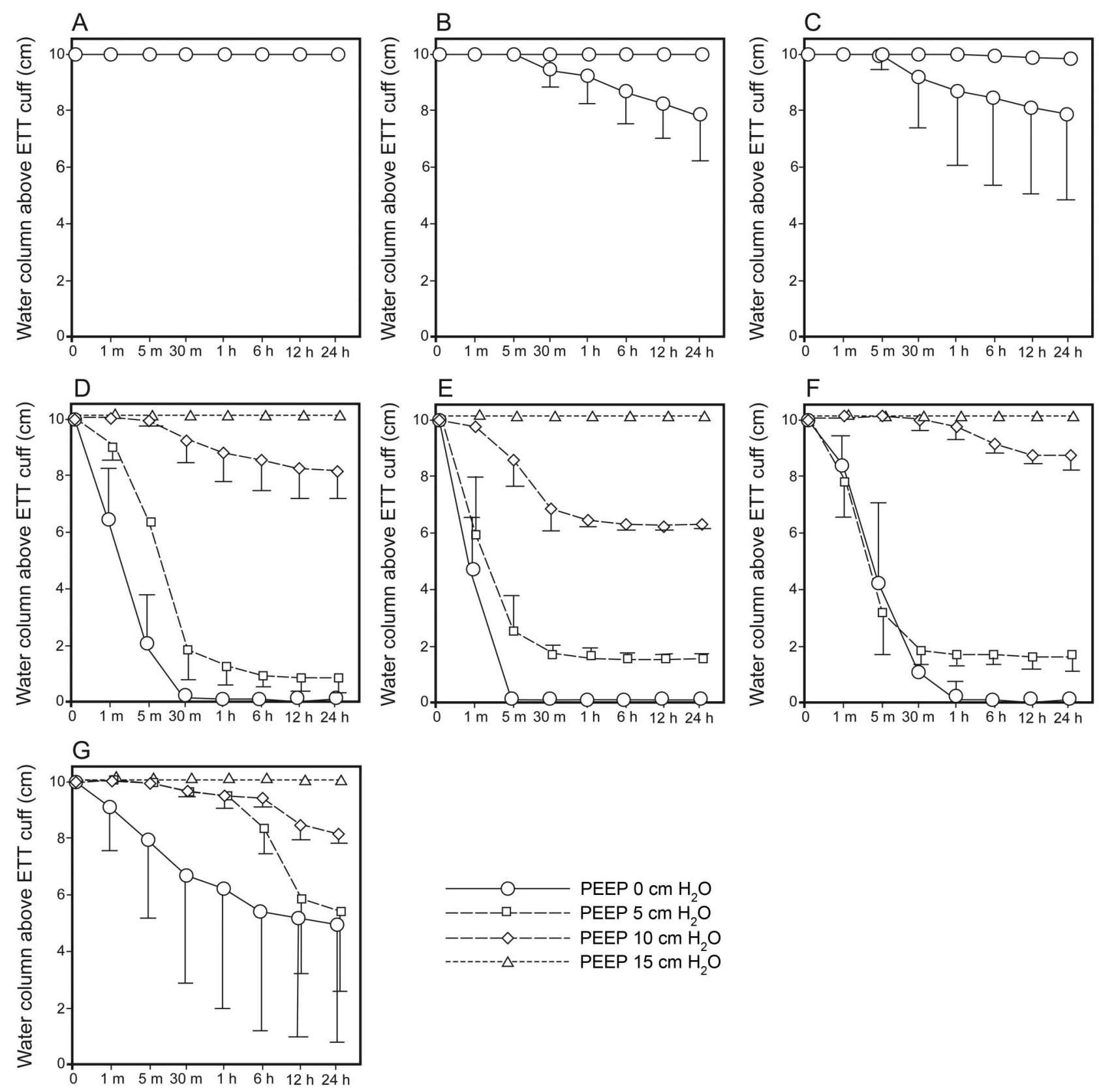

Fig. 9. At time zero, a water column of $10 \mathrm{~cm} \mathrm{H}_{2} \mathrm{O}$ was poured above the tested endotracheal tube (ETT) cuffs. The graphics represent the mean $\pm S D$ of the residual vertical height of the water column $(\mathrm{cm})$ at incremental times with PEEP $0,5,10$, and $15 \mathrm{~cm} \mathrm{H}_{2} \mathrm{O}$. A: Double-layer prototype (guayule latex, cylindrical). B: Microcuff (polyurethane, cylindrical). C: Mallinckrodt SealGuard (polyurethane, conical). D: Mallinckrodt Hi-Lo (PVC, cylindrical). E: Portex Ivory (PVC, cylindrical). F: Mallinckrodt High-Contour (PVC, cylindrical). G: Mallinckrodt TaperGuard (PVC, conical). From Reference 115, with permission.

Two recent clinical trials suggest mixed results using the tapered cuff. D'Haese et al ${ }^{127}$ randomized 60 subjects undergoing lumbar surgery to either cylindrical or tapered PVC-cuffed ETTs. Dye was injected above the cuff, and fluid leakage was assessed by bronchoscopy periodically for up to $2 \mathrm{~h}$. While dye in the trachea was seen in $20 \%$ of subjects with the cylindrical cuff, none was seen in those with the tapered cuff. Bowton et al ${ }^{128}$ reported the impact of a hospital-wide conversion from a standard cylindrical PVC-cuffed ETT to a tapered PVC-cuffed ETT. They reported no difference in VAP rate during either 6-month study period: mean monthly rate of $3.3 \pm 1.8 / 1,000$ ventilator days versus $2.8+2.0 / 1,000$ ventilator days for the cylindrical and tapered cuff groups, respectively, although the authors noted that their historic VAP rate was 5.8/1,000 ventilator days. ${ }^{128}$ 


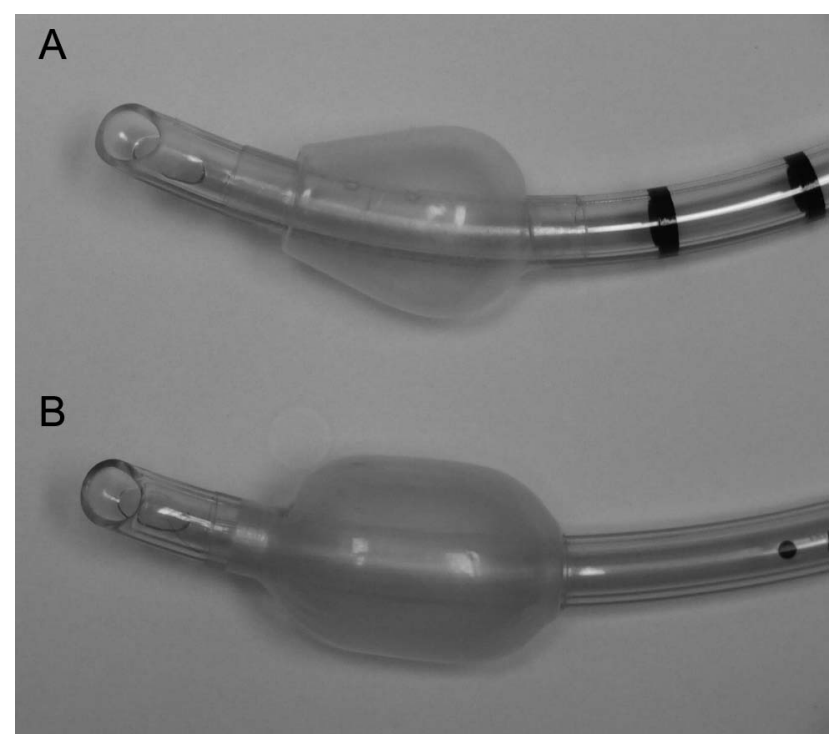

Fig. 10. A: Tapered or conical cuff shape. B: Standard cylindrical cuff shape.

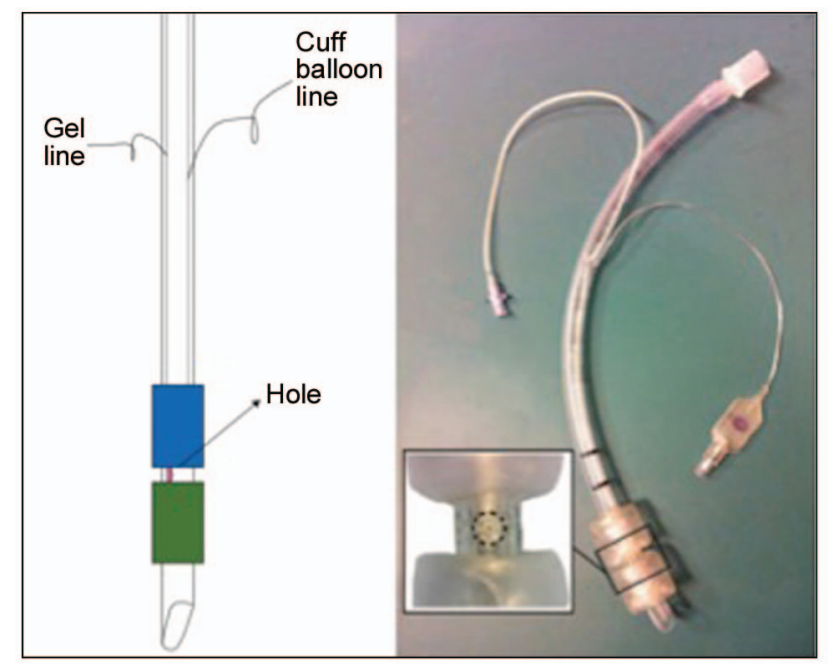

Fig. 11. Prototype double cuff. There is a small hole (1-mm diameter) between the 2 cuffs connected to a line for importing watersoluble gel (dotted circle). From Reference 129, with permission.

A novel cuff design recently reported by Hwang et al ${ }^{129}$ involves attaching a second PVC cuff to a standard ETT separated by $5 \mathrm{~mm}$ (Fig. 11). Between the cuffs is the outlet port of a line through which water-soluble gel is injected. Once the tube is in place and the cuffs are inflated, gel is injected to fill the gap. This tube was compared with 4 commercially available tubes (standard tracheal tube [Euromedical, Kedah, Malaysia], Mallinckrodt Hi-Lo [Covidien], Microcuff, and Mallinckrodt TaperGuard). In a leak test using dyed water over a 48-h period, the prototype did not leak. The Microcuff and TaperGuard leaked considerably less than the other tubes but more than the prototype. ${ }^{129}$ The authors noted that the gel tended to fill the cuff folds to prevent leakage. This tube has not been tested clinically.

Subglottic Secretion Drainage. With the ETT in place, secretions easily drain into the subglottic space and pool above the cuff. As noted earlier, these contaminated secretions leak down around the cuff and contribute to pneumonia. Another VAP prevention strategy is to aspirate these secretions using a special ETT system referred to as SSD. A modification to the standard ETT embeds a dedicated lumen in the dorsal wall of the tube exiting above the cuff. This line is used to evacuate secretions either continuously (continuous aspiration of subglottic secretions) when connected to a suction line at low vacuum or intermittently using wall suction or a syringe.

At least 12 randomized controlled trials (RCTs) have reported using a form of SSD in an attempt to reduce VAP (Table 1).92,94,115,130-138 Dezfulian et al95 reported a metaanalysis in 2005 of 5 RCTs with a total of 898 subjects. Four studies included subjects expected to be mechanically ventilated for $>72 \mathrm{~h}: 3$ studies from combined medical-surgical ICUs ${ }^{92,94,130}$ and one study from a surgical ICU. ${ }^{132}$ The fifth study included subjects following cardiac surgery regardless of expected duration of ventilation. ${ }^{131}$ The main finding was that SSD reduced VAP by $49 \%$ (risk reduction $0.51,95 \%$ CI $0.37-0.71$ ). When only including studies that enrolled subjects expected to require $>72 \mathrm{~h}$ of ventilation, SSD reduced the risk of VAP (risk reduction $0.50,95 \% \mathrm{CI} 0.35-0.71)$ and was associated with fewer days of ventilation (2 d) and ICU stay (3d). Since the 2005 meta-analysis, 7 other RCTs of SSD have been reported. Four meta-analyses of SSD have been published since 2011, analyzing different combinations of these studies (Table 2). ${ }^{139-142}$ Regardless of the combination of the studies included in the analysis, the results suggest that SSD results in a reduction of VAP by $\sim 50 \%$ and may be associated with reduced early onset of VAP, shorter duration of mechanical ventilation, and fewer days in the ICU, but not a reduced mortality.

Despite the strength of evidence of these meta-analyses, SSD has not been embraced by the critical care community. Potential barriers include perceived limitations of the individual RCTs, concern about tissue injury at site of the SSD port, maintaining patency of the aspiration line, predicting whether a patient will require more than $48-72 \mathrm{~h}$ of ventilation, and cost.

One of the early concerns with SSD is potential for tracheal injury at the site of the evacuation lumen above the cuff. In a sheep study, all animals receiving continuous aspiration of subglottic secretions had widespread posterior tracheal mucosa injury at the level of the suction port. ${ }^{143}$ A study investigating the mechanism of suction failure during continuous aspiration of subglottic secretions in 40 
Table 1. Randomized Trials of SSD

\begin{tabular}{|c|c|c|c|c|c|c|c|c|c|}
\hline Reference & $n$ & $\begin{array}{l}\text { Intermittent } \\
\text { vs CASS }\end{array}$ & $\begin{array}{l}\text { Minimum Time } \\
\text { of Mechanical } \\
\text { Ventilation }\end{array}$ & SSD ETT & $\begin{array}{l}\text { VAP Rate }(\%), \\
\text { SSD vs Control }\end{array}$ & $\begin{array}{l}\text { VAP Rate } \\
\text { (No./1,000 } \\
\text { Ventilator d) }\end{array}$ & $\begin{array}{l}\text { VAP RR } \\
(95 \% \mathrm{CI})\end{array}$ & $\begin{array}{l}\text { Time Until } \\
\text { VAP (d) }\end{array}$ & Country \\
\hline Mahul et al ${ }^{130}$ & 145 & Hourly, syringe & $>72 \mathrm{~h}$ & Hi-Lo Evac & 13 vs 29.1 & & & 16.2 vs 8.3 & France \\
\hline Vallés et al ${ }^{12}$ & 153 & CASS & $>72 \mathrm{~h}$ & Hi-Lo Evac & 18.4 vs 32.5 & 19.9 vs 39.6 & & $\begin{array}{c}12.0 \pm 7.1 \text { vs } \\
5.5 \pm 2.1 \\
(P<.001)\end{array}$ & Spain \\
\hline Kollef et al ${ }^{131}$ & 343 & $\begin{array}{l}\text { Intermittent } \\
\quad(<20 \mathrm{~mm} \mathrm{Hg})\end{array}$ & ND & Hi-Lo Evac & 5.0 vs $8.2(P=.24)$ & $\begin{array}{r}34.5 \text { vs } 43.2 \\
(P=.24)\end{array}$ & $0.61(0.27-1.40)$ & $\begin{array}{c}5.6 \pm 2.3 \text { vs } \\
2.9 \pm 1.2 \\
(P=.006)\end{array}$ & USA \\
\hline Bo et $\mathrm{al}^{132}$ & 68 & CASS & $>72 \mathrm{~h}$ & NR & 23 vs $45(P<.05)$ & & & $14 \underset{(P<.05)}{ \pm}$ vs $6 \pm 4$ & China \\
\hline Smulders et al ${ }^{94}$ & 150 & $\begin{array}{l}\text { Intermittent, } \\
\text { every } \\
20 \mathrm{~s} \times 8 \mathrm{~s} \mathrm{at} \\
100 \mathrm{~mm} \mathrm{Hg}\end{array}$ & $>72 \mathrm{~h}$ & Hi-Lo Evac & $\begin{array}{l}\text { All subjects: } \\
\quad 4 \text { vs } 16(P=.01) \\
\text { > } 72 \mathrm{h:} \\
6.6 \text { vs } 21.3 \\
(P<.001)\end{array}$ & $\begin{array}{l}9.2 \text { vs } 22.5 \\
\quad(P<.001)\end{array}$ & $0.22(0.06-0.81)$ & & Netherlands \\
\hline Girou et al ${ }^{133}$ & 18 & CASS & $>5 \mathrm{~d}$ & Hi-Lo Evac & 62.5 vs 60 & & & $\begin{array}{l}7.7 \text { vs } 4.6 \\
\quad(P<.05)\end{array}$ & France \\
\hline Liu et $\mathrm{al}^{134}$ & 86 & Unknown & $>48 \mathrm{~h}$ & $\begin{array}{l}\text { Not in } \\
\text { abstract }\end{array}$ & $\begin{array}{l}6.0 \text { vs } 20.0 \\
(P<.05)\end{array}$ & & & $\begin{array}{c}7.7 \pm 3.2 \text { vs } \\
4.6 \pm 2.1 \\
(P<.05)\end{array}$ & China \\
\hline Lorente et al ${ }^{116}$ & 280 & Hourly, syringe & $>24 \mathrm{~h}$ & $\begin{array}{l}\text { SealGuard } \\
\text { Evac }\end{array}$ & $\begin{array}{l}7.9 \text { vs } 22.1 \\
\quad(P=.001)\end{array}$ & $\begin{array}{l}7.5 \text { vs } 19.9 \\
\quad(P=.003)\end{array}$ & & $\begin{array}{c}10.3 \pm 11.1 \mathrm{vs} \\
7.2 \pm 5.3 \\
(P=.36)\end{array}$ & Spain \\
\hline Bouza et al ${ }^{135}$ & 714 & CASS & ND & Hi-Lo Evac & $\begin{array}{l}\text { All subjects: } \\
3.6 \text { vs } 5.3 \\
(P=.20) \\
>48 \mathrm{h:} \\
26.7 \text { vs } 47.5 \\
(P=.04)\end{array}$ & $\begin{array}{l}\text { All subjects: } \\
\quad 17.9 \text { vs } 27.6 \\
(P=.18) ; \\
>48 \mathrm{h:} \\
31.5 \text { vs } 51.6 \\
(P=.03)\end{array}$ & $0.67(0.32-1.4)$ & 8.5 vs 8.0 & Spain \\
\hline Yang et al ${ }^{136}$ & 91 & CASS & $>48 \mathrm{~h}$ & $\begin{array}{l}\text { Not in } \\
\text { abstract }\end{array}$ & $\begin{array}{l}25.0 \text { vs } 46.5 \\
(P=.032)\end{array}$ & & & $\begin{array}{c}7.3 \pm 4.2 \text { vs } \\
5.1 \pm 3.0 \\
(P=.10)\end{array}$ & China \\
\hline Zheng et al ${ }^{137}$ & 61 & Unknown & $>48 \mathrm{~h}$ & $\begin{array}{l}\text { Not in } \\
\text { abstract }\end{array}$ & $\begin{array}{c}30.0 \text { vs } 51.6 \\
(P<.05)\end{array}$ & & & $\begin{array}{r}6.5 \pm 1.3 \text { vs } \\
5.5 \pm 0.6 \\
(P>.05)\end{array}$ & China \\
\hline Lacherade et al ${ }^{138}$ & 333 & Hourly, syringe & $>48 \mathrm{~h}$ & Hi-Lo Evac & $\begin{array}{c}14.8 \text { vs } 25.6 \\
(P=.02)\end{array}$ & $\begin{array}{l}17 \text { vs } 34 \\
\quad(P=.002)\end{array}$ & $0.58(0.37-0.90)$ & & France \\
\hline $\begin{array}{l}\text { CASS }=\text { continuous a } \\
\text { SSD }=\text { subglottic secr } \\
\text { ETT }=\text { endotracheal } \\
\text { VAP }=\text { ventilator-ass } \\
\text { RR }=\text { risk reduction } \\
\text { ND }=\text { not done } \\
\text { NA }=\text { not applicable } \\
\text { NR }=\text { not reported }\end{array}$ & $\begin{array}{l}\text { piratior } \\
\text { tion dr } \\
\text { be } \\
\text { ciated }\end{array}$ & $\begin{array}{l}\text { of subglottic secretio } \\
\text { ainage } \\
\text { neumonia }\end{array}$ & & & & & & & \\
\hline
\end{tabular}

adults determined that the system failed in 19 subjects $(47.5 \%)$. In 17 of the 19 failures, bronchoscopy determined that the subglottic suction lumen was blocked by tracheal mucosa; one subject had a mucus plug, and the other was undetermined due to poor bronchoscopic visibility. ${ }^{144}$ Harvey et al ${ }^{145}$ reported 2 cases of tracheoesophageal fistula that appeared to be in the vicinity of the SSD suction port. Another study using continuous aspiration of subglottic secretions reported a $40 \%$ incidence of postextubation laryngeal edema and considered it an adverse outcome of SSD. ${ }^{133}$ These issues have not been reported using intermittent SSD, and given that the intermittent method appears to affect VAP similarly as continuous aspiration, ${ }^{140}$ intermittent SSD may be preferred.

In addition to plugging with tracheal tissue, system failure can also be due to plugging with secretions. One study reported an SSD failure rate of 34\% (28 of 83 subjects) and that this failure was associated with a higher incidence of VAP. ${ }^{88}$ Modifications to the tube to address these issues include a larger diameter of the lumen to reduce plugging from mucus and moving the aspiration lumen closer to the cuff so the opening is farther from the tracheal wall. ${ }^{146}$

SSD appears to be most effective when applied to patients requiring $>72 \mathrm{~h}$ of ventilation, but it is difficult to determine which patients will require a lengthy course of ventilation before intubation. Unfortunately, the RCTs claiming to have used SSD on subjects requiring $>72 \mathrm{~h}$ of ventilation did not provide explicit criteria used to determine these patients.

Although the cost of an SSD ETT is considerable more than that of a standard tube (approximately $\$ 10-30$ vs $\$ 1-2)$, it has been suggested to be cost-effective. ${ }^{147-150}$ For example, Shorr and O'Malley ${ }^{147}$ calculated a net savings of $\$ 4,992$ per VAP case, assuming that the SSD ETT was used on all nonelective intubations (irrespective of anticipated duration of ventilation); a VAP incidence of $25 \%$ in 
Table 2. Summary of the Five Meta-Analyses of Subglottic Secretion Drainage

\begin{tabular}{|c|c|c|c|c|c|c|c|c|}
\hline \multirow[b]{2}{*}{ Reference } & \multirow{2}{*}{$\begin{array}{l}\text { No. } \\
\text { RCTs }\end{array}$} & \multirow{2}{*}{$\begin{array}{l}\text { Subjects } \\
(n)\end{array}$} & \multirow{2}{*}{$\begin{array}{l}\text { VAP RR } \\
(95 \% \text { CI) }\end{array}$} & \multirow{2}{*}{$\begin{array}{l}\text { Reduced } \\
\text { Ventilator } \\
\text { Time (d) }\end{array}$} & \multirow{2}{*}{$\begin{array}{l}\text { Time to } \\
\text { First VAP } \\
\text { (d) }\end{array}$} & \multicolumn{2}{|c|}{ VAP RR } & \multirow{2}{*}{$\begin{array}{c}\text { Hospital } \\
\text { Mortality RR } \\
(95 \% \mathrm{CI})\end{array}$} \\
\hline & & & & & & $\begin{array}{c}\text { Intermittent } \\
(95 \% \text { CI })\end{array}$ & $\begin{array}{c}\text { CASS } \\
(95 \% \text { CI) }\end{array}$ & \\
\hline Dezfulian et al95 & 5 & 896 & $0.51(0.37-0.71)$ & $2(1.7-2.3)^{*}$ & $6.8(5.5-8.1)$ & & & \\
\hline Muscedere et al ${ }^{139}$ & 13 & 2,442 & $0.55(0.46-0.66)$ & $1.1(0.1-2.0)$ & $2.7(1.1-4.3)$ & $0.59(0.47-0.74)$ & $0.50(0.37-0.66)$ & $0.97(0.83-1.13)$ \\
\hline Wang et al ${ }^{140}$ & 10 & 2,213 & $0.56(0.45-0.69)$ & $1.6(0.7-2.4)$ & $3.9(2.6-5.2)$ & $0.49(0.34-0.71)$ & $0.61(0.46-0.79)$ & $0.97(0.84-1.12)$ \\
\hline Leasure et al ${ }^{141}$ & 10 & 1,709 & $0.52(0.43-0.64)$ & $2(1.7-2.3)^{*}$ & & & & $0.93(0.81-1.06)$ \\
\hline Frost et al ${ }^{142}$ & 9 & 2,280 & $0.52(0.42-0.65)$ & $2(1.6-2.3)^{*}$ & $2.9(0.1-5.7)$ & & & $0.96(0.81-1.12)$ \\
\hline $\begin{array}{l}* \text { Excluded the Kollef st } \\
\text { RCTs }=\text { randomized con } \\
\text { VAP }=\text { ventilator-associ } \\
\text { RR }=\text { risk reduction } \\
\text { CASS }=\text { continuous aspi }\end{array}$ & $\begin{array}{l}\text { y (no requi } \\
\text { olled trials } \\
\text { d pneumor } \\
\text { tion of sub }\end{array}$ & ottic secretio & pated duration of mechar & ical ventilation $)^{131}$ & & & & \\
\hline
\end{tabular}

subjects requiring $>72 \mathrm{~h}$ of ventilation (in 2001); and a $30 \%$ relative risk reduction using SSD. A recent French study came to a similar conclusion using more conservative assumptions. ${ }^{148}$

Several evidence-based VAP prevention guidelines have already included SSD as a recommended strategy. ${ }^{151-155}$ Hopefully, additional high-quality studies will evaluate SSD, and further system modifications can be made to ensure patient safety and tube functionality. If secretions are not evacuated with SSD, deep oropharyngeal aspiration with a long, soft, flexible catheter may be similarly effective in preventing VAP. Two studies used this technique when changing the subject's position or manipulating the ETT found reduced VAP rates. ${ }^{156,157}$

\section{Reducing the Formation and Presence of Biofilm}

Reducing Biofilm Formation. The surface of ETTs becomes coated with a layer of biologic material and bacteria within hours of intubation, eventually forming what is known as a biofilm. ${ }^{158} \mathrm{~A}$ biofilm is defined as a structured community of bacterial cells enclosed in a self-producing polymeric matrix and adhered to an inert or living surface. ${ }^{159}$ These bacteria are protected within the biofilm, eluding host defense mechanisms and systemic antimicrobials. During respiratory procedures, such as suctioning, bronchoscopy, and instillation, biofilm aggregates can detach and migrate deeper into the lungs. It has also been shown that bacteria from the biofilm can be entrained in the inspiratory gas flow of the ventilator. ${ }^{96}$ Biofilm is increasingly being considered as a major source for VAP, as a high percentage of patients with VAP $(55-70 \%)$ have the same pathogen in their tracheal secretions and ETT biofilm. ${ }^{97,158}$

Because systemic antibiotics cannot reach the bacteria within the ETT biofilm, there is considerable interest in using antimicrobial agents in coating the ETT to prevent or reduce biofilm formation. Several agents have been identified and studied, but only silver has been subjected to multiple clinical trials. Silver has broad-spectrum antimicrobial effects and is a common agent used for wound and burn dressings. ${ }^{160}$ It has been shown to reduce the bacterial adhesion to devices in vitro ${ }^{161-164}$ and to reduce ETT biofilm formation and delay of lung colonization in animal models. ${ }^{165-167}$

Two RCTs using silver-coated ETTs have been reported. Rello et al ${ }^{168}$ described a study of 149 subjects anticipated to be mechanically ventilated for $>24 \mathrm{~h}$ who were randomized to either a standard ETT or a silver-coated ETT (CR Bard, Covington, Georgia). The main objective was to determine device feasibility and safety and its effect on bacterial burden in the airway. VAP rates were not determined, but the silver-coated tube was associated with delayed colonization of the ETT and lower maximum bacterial burden in tracheal aspirates for $7 \mathrm{~d}$. Although the silver-coated tube was delayed in timing, all ETTs were eventually colonized. ${ }^{169}$ The North American SilverCoated Endotracheal Tube (NASCENT) study randomized 2,003 adults expected to be mechanically ventilated for $>24 \mathrm{~h}$ to either a silver-coated ETT or a standard ETT. ${ }^{170}$ Of the 1,509 subjects who required $>24 \mathrm{~h}$ of ventilation, the VAP rate was $4.8 \%$ (95\% CI 3.4-6.6) for the study group and 7.5\% (95\% CI 5.7-9.7) for the control group $(P=.03)$, which demonstrates a $35.9 \%$ relative risk reduction using the silver-coated tube. The silver-coated tube was also associated with delayed occurrence of VAP $(P=.005)$, but not reduced mortality, duration of ventilation, or duration of ICU or hospital stay. A recent systematic review of the topic found only these 2 studies to pool in analysis. ${ }^{171}$ The authors concluded, however, that the limited amount of evidence showed that silver-coated ETTs reduced VAP incidence, microbiologic burden, and device-related adverse events and that additional studies are needed to confirm these findings. ${ }^{171}$ 


\section{ENDOTRACHEAL TUBES}

A retrospective cohort analysis of the NASCENT study in 2010 determined that silver-coated ETTs were associated with a reduced mortality in subjects who developed VAP (14\% vs $36 \%, P=.03) .{ }^{172}$ Unexpectedly and unexplainably, the mortality rate was higher in those who used the silver-coated ETTs but did not develop VAP (31\% vs $26 \%, P=.03) .172$

One deterrent to using this tube is determining which patients should receive the tube. Similar to the evidence with SSD ETTs, the silver-coated tube is most effective in patients requiring prolonged ventilation, and it is difficult to determine who they are at the time of initial intubation. Another perceived deterrent to using the silver-coated tube is cost. A cost-effectiveness analysis of silver-coated ETTs in preventing VAP used the following assumptions in the model: tube placement in all nonelective intubations, VAP risk of $9.7 \%$ using uncoated ETTs, VAP relative risk reduction of $24 \%$ using silver-coated ETTs, marginal hospital costs of $\$ 16,620$, and a cost of $\$ 90$ for the silvercoated tube and $\$ 2$ for the uncoated tube. ${ }^{173}$ The cost savings per case of VAP prevented was determined to be $\$ 12,840$. Using these same assumptions, a breakeven point was estimated to be $\$ 388$, meaning that the cost of the coated tube would have to increase to $\$ 388$ to offset the savings per case.

An advantage of the coated tube is that once it is in place, clinicians are not required to interact with it, as opposed to SSD, which relies on clinician monitoring or interaction to be effective. In addition to silver, there is interest in other agents that might be used to coat or impregnate the ETT to inhibit bacterial growth. ${ }^{174-181}$ None of them have yet been advanced to clinical trials.

Removing Biofilm. Several reports have described devices that mechanically clean or shave secretions and biofilm from the ETT. The Mucus Shaver consists of a long plastic tube with an inflatable balloon and several silicone rubber shaving rings near the end of the tube. ${ }^{182}$ When the balloon is inflated, the shaving rings are pressed against the ETT wall, and mucus is scraped from the ETT surface as the device is withdrawn through the ETT. The catheter was tested in a randomized trial of 25 subjects expected to be mechanically ventilated for $>72 \mathrm{~h} .{ }^{183}$ The control group received standard endotracheal suctioning every $6 \mathrm{~h}$, and the study group received standard suctioning followed by a single pass of the device. No adverse events were reported, and at extubation, fewer ETTs were colonized in the study group ( $8 \%$ vs $83 \%, P<.001)$, and their internal lumens were visibly clean. This device may contribute to improving the effectiveness and duration of the antimicrobial properties of silver-coated ETTs. ${ }^{184}$ At present, the Mucus Shaver is not commercially available. The CAM Rescue Cath (Omneotech, Tavernier, Florida) is a similar

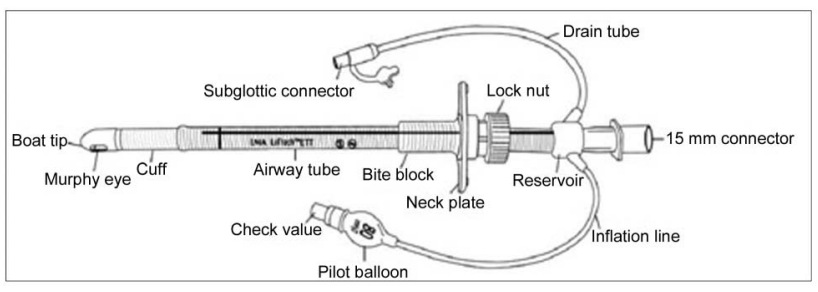

Fig. 12. The PneuX endotracheal tube (formerly known as the Young Lo-Trach). Courtesy Venner Medical.

device that uses a mesh balloon rather than shaving ring to clean the ETT lumen. This product is available and was recently described in a case series of 3 patients presenting with partially obstructed airways relieved by cleaning their ETTs. ${ }^{185}$ Another commercially available ETT biofilm cleaner is the endOclear (Endoclear, Petoskey, Michigan), which uses a unique wiper to scrape the ETT inner surface. Removing the biofilm and secretions within the ETT helps reduce the airway resistance and associated work of breathing and may be important in addressing ventilator weaning failure in certain patients. ${ }^{186,187}$

\section{An ETT Bundle?}

Current VAP prevention strategies incorporate several best practices into a bundle in an attempt to build on potential synergies of various evidence-based efforts. ${ }^{188,189}$ The same may apply to a redesign of the ETT. Incorporating multiple features shown to have benefit in reducing VAP, as well as minimizing other ETT-related complications, may be desirable. There have been several prototypes of this concept, but most are not available nationally and have not been subjected to clinical trials.

The PneuX ETT (Venner Medical, Singapore) incorporates multiple innovations and is available in Europe (Fig. 12). ${ }^{190}$ It is a straight, flexible, wire-reinforced tube with a low-volume low-pressure silicone cuff and an atraumatic tip. The cuff design requires an intracuff pressure of $80 \mathrm{~cm} \mathrm{H}_{2} \mathrm{O}$ to apply $30 \mathrm{~cm} \mathrm{H}_{2} \mathrm{O}$ of pressure to the tracheal wall. It forms no folds in the cuff when inflated, and it has been shown to prevent aspiration and perform better than standard cuffs in a bench study, a pig model, anesthetized patients, and critically ill patients. ${ }^{191,192}$ Its SSD system has 3 ports to improve performance and reduce tissue trauma. Because the cuff prevents fluid leakage so efficiently, it is recommended that the port also be used to lavage the entire supracuff airway. A nonstick coating lines the interior lumen to help prevent biofilm formation. The tube is meant to be used with a proprietary automated cuff management system that maintains a consistent intracuff pressure. 


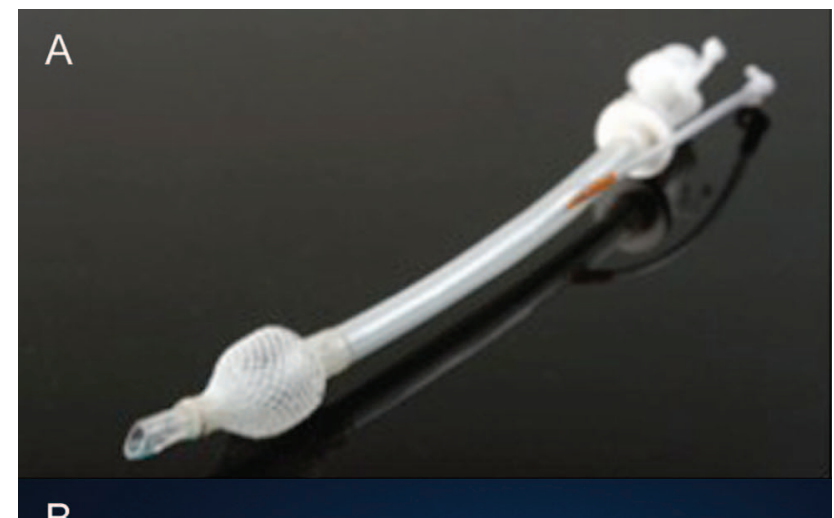

B

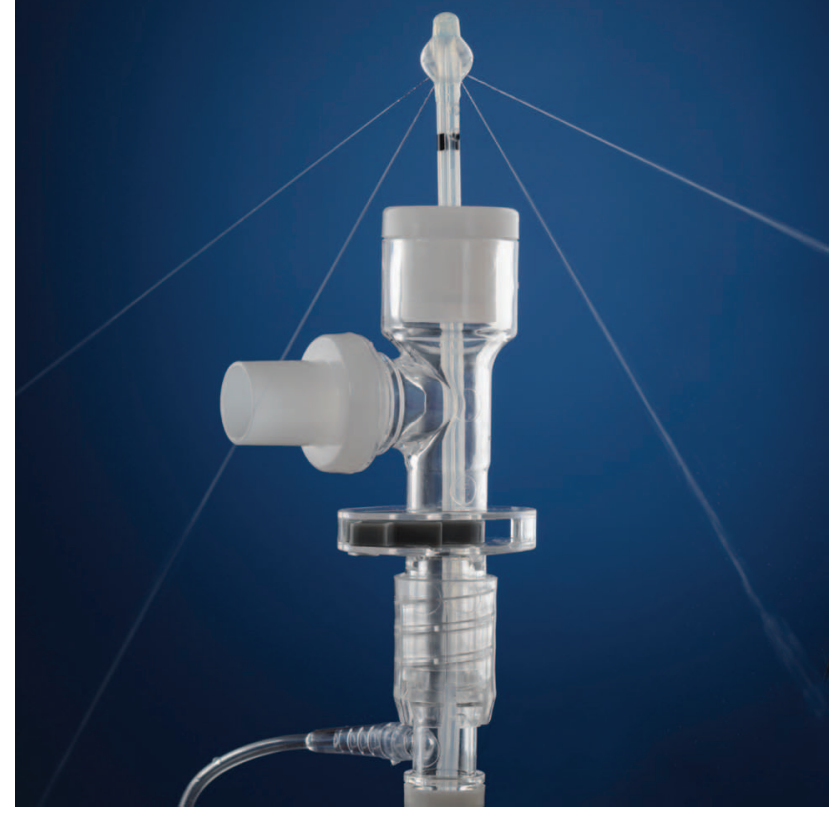

Fig. 13. A: The Airway Medix endotracheal tube. B: the closedsuction catheter system. Courtesy Biovo Technologies.

Another innovative system is the Airway Medix ETT and closed-suction system (Biovo Technologies, Tel Aviv, Israel). The ETT replaces the balloon cuff with a selfexpanding stent-like sleeve that is claimed to create an effective seal without applying excessive tracheal wall pressure (Fig. 13A). Secretions that drain into the cuff can be aspirated via a subglottic aspiration line. The closed-suction system includes a mechanism to spray the internal ETT lumen to clean biofilm (Fig. 13B). There are no bench studies or clinical trials of this device, but product information is available online (http://www.biovo.net/airwaymedix).

\section{Summary}

This review has highlighted a wide variety of permutations of the ETT to address special needs, particularly in the operating room. For the critical care clinician, although minimizing patient harm due to trauma from high cuff pressure is important, a major focus needs to be on minimizing the factors known to cause VAP. More evidence is required before strong recommendations can be made about these new design features.

\section{REFERENCES}

1. White GM. Evolution of endotracheal and endobronchial intubation. Brit J Anaesth 1960;32(5):235-246.

2. Dunn PF, Goulet RL. Endotracheal tubes and airway appliances. Int Anesthesiol Clin 2000;38(3):65-94.

3. Rosenberg H, Axelrod JK. The introduction and popularization of endotracheal intubation into anesthesia practice. Bull Anesth Hist 2003;21(4):1,4-6.

4. Doyle DJ. A brief history of clinical airway management. Revista Mexicana Anesthesiol 2009;32(Suppl 1):S164-S167.

5. Carroll RG, McGinnis GE, Grenvik A. Performance characteristics of tracheal cuffs. Int Anesthesiol Clin 1974;12(3):111-142.

6. Brodsky JB, Lemmens HJ. The history of anesthesia for thoracic surgery. Minerva Anestesiol 2007;73(10):513-524.

7. Westhorpe R. Kuhn's endotracheal tube. Anaesth Intensive Care 1991;19(4):489.

8. Thierbach A. Franz Kuhn, his contribution to anaesthesia and emergency medicine. Resuscitation 2001;48(3):193-197.

9. Robinson DH, Toledo AH. Historical development of modern anesthesia. J Invest Surg 2012;25(3):141-149.

10. Watson WF. Development of the PVC endotracheal tube. Biomaterials 1980;1(1):41-46.

11. Efrati S, Deutsch I, Gurman GM. Endotracheal tube cuff-small important part of a big issue. J Clin Monit Comput 2012;26(1):5360.

12. Cooper JD, Grillo HC. Analysis of problems related to cuffs on intratracheal tubes. Chest 1972;62(2 Suppl):21S-27S.

13. Colice GL. Technical standards for tracheal tubes. Clin Chest Med 1991;12(3):433-448.

14. Shelly WM, Dawson RB, May IA. Cuffed tubes as a cause of tracheal stenosis. J Thorac Cardiovasc Surg 1969;57(5):623-627.

15. Hedden M, Ersoz CJ, Donnelly WH, Safar P. Laryngotracheal damage after prolonged use of orotracheal tubes in adults. JAMA 1969; 207(4):703-708.

16. Cooper JD, Grillo HC. The evolution of tracheal injury due to ventilatory assistance through cuffed tubes: a pathologic study. Ann Surg 1969;169(3):334-348.

17. Miller DR, Sethi G. Tracheal stenosis following prolonged cuffed intubation: cause and prevention. Ann Surg 1970;171(2):283-293.

18. Geffin B, Pontoppidan H. Reduction of tracheal damage by the prestretching of inflatable cuffs. Anesthesiology 1969;31(5):462463.

19. Bjork VO, Carlens E. The prevention of spread during pulmonary resection by the use of a double-lumen catheter. J Thorac Surg 1950;20(1):151-157.

20. Strange C. Double-lumen endotracheal tubes. Clin Chest Med 1991; 12(3):497-506.

21. Campos JH. Which device should be considered the best for lung isolation: double-lumen endotracheal tube versus bronchial blockers. Curr Opin Anaesthesiol 2007;20(1):27-31. 


\section{ENDOTRACHEAL TUBES}

22. Campos JH. Lung isolation techniques for patients with difficult airway. Curr Opin Anaesthesiol 2010;23(1):12-17.

23. Ueda K, Goetzinger C, Gauger EH, Hallam EA, Campos JH. Use of bronchial blockers: a retrospective review of 302 cases. J Anesth 2012;26(1):115-117.

24. Ghosh S, Falter F, Goldsmith K, Arrowsmith JE. The Papworth BiVent tube: a new device for lung isolation. Anaesthesia 2008; 63(9):996-1000.

25. Ghosh S, Klein AA, Prabhu M, Falter F, Arrowsmith JE. The Papworth BiVent tube: a feasibility study of a novel double-lumen endotracheal tube and bronchial blocker in human cadavers. $\mathrm{Br} \mathrm{J}$ Anaesth 2008;101(3):424-428.

26. Ghosh S, Falter F, Klein AA, Arrowsmith JE. The Papworth BiVent tube: initial clinical experience. J Cardiothorac Vasc Anesth 2011; 25(3):505-508.

27. Ring WH, Adair JC, Elwyn RA. A new pediatric endotracheal tube. Anesth Analg 1975;54(2):273-274.

28. Strong MS, Jako GJ. Laser surgery in the larynx. Early clinical experience with continuous $\mathrm{CO}_{2}$ laser. Ann Otol Rhinol Laryngol 1972;81(6):791-798.

29. Sheinbein DS, Loeb RG. Laser surgery and fire hazard in ear, nose, and throat surgeries. Anesthesiol Clin 2010;28(3):485-496.

30. Hermens JM, Bennett MJ, Hirshman CA. Anesthesia for laser surgery. Anesth Analg 1983;62(2):218-229.

31. Denton RA, Dedhia HV, Abrons HL, Jain PR, Lapp NL, Teba L. Long-term survival after endobronchial fire during treatment of severe malignant airway obstruction with Nd:YAG laser. Chest 1988;94(5):1086-1088.

32. Krawtz S, Mehta AC, Wiedemann HP, DeBoer G, Schoepf KD, Tomaszewski MZ. Nd-YAG laser-induced endobronchial burn. Management and long-term follow-up. Chest 1989;95(4):916-918.

33. De Vane GG. Laser initiated endotracheal tube explosion. AANA J 1990;58(3):188-192.

34. Lai HC, Juang SE, Liu TJ, Ho WM. Fires of endotracheal tubes of three different materials during carbon dioxide laser surgery. Acta Anaesthesiol Sin 2002;40(1):47-51.

35. Stuermer KJ, Ayachi S, Gostian AO, Beutner D, Hüttenbrink KB. Hazard of $\mathrm{CO}_{2}$ laser-induced airway fire in laryngeal surgery: experimental data of contributing factors. Eur Arch Otorhinolaryngol 2013;270(10):2701-2707.

36. Bhat AG, Ganapathi P. "Blow-torch phenomenon" during laser assisted excision of a thyroglossal cyst at the base of the tongue. $\mathrm{J}$ Anaesthesiol Clin Pharmacol 2012;28(2):247-248.

37. Hayes DM, Gaba DM, Goode RL. Incendiary characteristics of a new laser-resistant endotracheal tube. Otolaryngol Head Neck Surg 1986;95(1):37-40.

38. Treyve E, Yarington CT Jr, Thompson GE. Incendiary characteristics of endotracheal tubes with the carbon dioxide laser. Ann Otol Rhinol Laryngol 1981;90(4 Pt 1):328-330.

39. Sosis MB. Which is the safest endotracheal tube for use with the $\mathrm{CO}_{2}$ laser? A comparative study. J Clin Anesth 1992;4(3):217-219.

40. Mohan A, Guleria R, Mohan C, Sharma R. Laser bronchoscopycurrent status. J Assoc Physicians India 2004;52(11):915-920.

41. Rubinstein M, Armstrong WB. Transoral laser microsurgery for laryngeal cancer: a primer and review of laser dosimetry. Lasers Med Sci 2011;26(1):113-124.

42. Li S, Chen L, Tan F. Laryngeal surgery using a $\mathrm{CO}_{2}$ laser: is a polyvinylchloride endotracheal tube safe? Am J Otolaryngol 2012; 33(6):714-717.

43. Tsai CJ, Tseng KY, Wang FY, Lu IC, Wang HM, Wu CW, et al. Electromyographic endotracheal tube placement during thyroid surgery in neuromonitoring of recurrent laryngeal nerve. Kaohsiung J Med Sci 2011;27(3):96-101.
44. Fukuda M, Oishi M, Hiraishi T, Saito A, Fujii Y. Pharyngeal motor evoked potentials elicited by transcranial electrical stimulation for intraoperative monitoring during skull base surgery. J Neurosurg 2012;116(3):605-610.

45. Harries AM, Dong CC, Honey CR. Use of endotracheal tube electrodes in treating glossopharyngeal neuralgia: technical note. Stereotact Funct Neurosurg 2012;90(3):141-144.

46. Ito E, Ichikawa M, Itakura T, Ando H, Matsumoto $\mathrm{Y}$, Oda K, et al. Motor evoked potential monitoring of the vagus nerve with transcranial electrical stimulation during skull base surgeries. J Neurosurg 2013;118(1):195-201.

47. Mikuni N, Satow T, Taki J, Nishida N, Enatsu R, Hashimoto N. Endotracheal tube electrodes to map and monitor activities of the vagus nerve intraoperatively. Technical note. J Neurosurg 2004; 101(3):536-540.

48. Birkholz T, Saalfrank-Schardt C, Irouschek A, Klein P, Albrecht S, Schmidt J. Comparison of two electromyographical endotracheal tube systems for intraoperative recurrent laryngeal nerve monitoring: reliability and side effects. Langenbecks Arch Surg 2011; 396(8):1173-1179.

49. Berkow L, Dackiw AP, Tufano RP. Use of the GlideScope for placement of a recurrent laryngeal nerve monitoring endotracheal tube. J Clin Anesth 2011;23(1):81-83.

50. Capra GG, Shah AN, Moore JD, Halsey WS, Lujan E. Siliconebased endotracheal tube causing airway obstruction and pneumothorax. Arch Otolaryngol Head Neck Surg 2012;138(6):588-591.

51. Marfin AG, Iqbal R, Mihm F, Popat MT, Scott SH, Pandit JJ. Determination of the site of tracheal tube impingement during nasotracheal fibreoptic intubation. Anaesthesia 2006;61(7):646-650.

52. Xue FS, Xiong J, Yuan YJ, Wang Q. The Parker Flex-Tip tube for nasotracheal intubation (letter). Anaesthesia 2010;65(4):417; author reply 417-418.

53. Kristensen MS. The Parker Flex-Tip tube versus a standard tube for fiberoptic orotracheal intubation. Anesthesiology 2003;98(2):354358.

54. Sanuki T, Hirokane M, Matsuda Y, Sugioka S, Kotani J. The Parker Flex-tip tube for nasotracheal intubation: the influence on nasal mucosal trauma. Anaesthesia 2010;65(1):8-11.

55. Prior S, Heaton J, Jatana KR, Rashid RG. Parker Flex-Tip and standard-tip endotracheal tubes: a comparison during nasotracheal intubation. Anesth Prog 2010;57:18-24.

56. Sugiyama K, Manabe Y, Kohjitani A. The Parker Flex-Tip tube prevents subglottic impingement on the tracheal wall during nasotracheal intubation. Anesth Analg 2012;115(1):212-213.

57. Kitagawa H, Imashuku Y, Yamazaki T. The Parker Flex-Tip tube is useful in a bougie-assisted endotracheal tube exchange after lung lavage. J Cardiothorac Vasc Anesth 2010;24(5):901.

58. Blitt CD, Munson ES. Case report: complete obstruction of an armored endotracheal tube. Anesth Analg 1974;53(4):624-625.

59. Spiess BD, Rothenberg DM, Buckley S. Complete airway obstruction of armored endotracheal tubes. Anesth Analg 1991;73(1):9596.

60. Harrison P, Bacon DR, Lema MJ. Perforation and partial obstruction of an armored endotracheal tube. J Neurosurg Anesthesiol 1995;7(2):121-123.

61. Rajkumar A, Bajekal R. Intraoperative airway obstruction due to dissection of a reinforced endotracheal tube in a prone patient. J Neurosurg Anesthesiol 2011;23(4):377.

62. Hunsaker DH. Anesthesia for microlaryngeal surgery: the case for subglottic jet ventilation. Laryngoscope 1994;104(8 Pt 2 Suppl 65): $1-30$.

63. Brooker CR, Hunsaker DH, Zimmerman AA. A new anesthetic system for microlaryngeal surgery. Otolaryngol Head Neck Surg 1998;118(1):55-60. 


\section{ENDOTRACHEAL TUBES}

64. Davies JM, Hillel AD, Maronian NC, Posner KL. The Hunsaker Mon-Jet tube with jet ventilation is effective for microlaryngeal surgery. Can J Anaesth 2009;56(4):284-290.

65. Hu A, Weissbrod PA, Maronian NC, Hsia J, Davies JM, Sivarajan GK, Hillel AD. Hunsaker Mon-Jet tube ventilation: a 15 year experience. Laryngoscope 2012;122(10):2234-2239.

66. Andrzejowski J, Francis G. The efficacy of lidocaine administration via the LITA tracheal tube in attenuating the extubation response in beta-blocking patients following craniotomy. Anaesthesia 2002; 57(4):399-401.

67. Yamasaki H, Takahashi K, Yamamoto S, Yamamoto Y, Miyata Y, Terai T. Efficacy of endotracheal lidocaine administration with continuous infusion of remifentanil for attenuating tube-induced coughing during emergence from total intravenous anesthesia. J Anesth 2013;27(6):822-826.

68. Lanz E, Zimmerschitt W. [Volume and pressure change due to nitrous oxide diffusion in customary and in low-pressure cuffs of endotracheal tubes]. Anaesthesist 1976;25(10):491-498. Article in German.

69. Leigh JM, Maynard JP. Pressure on the tracheal mucosa from cuffed tubes. BMJ 1979;1(6172):1173-1174.

70. Seegobin RD, van Hasselt GL. Endotracheal cuff pressure and tracheal mucosal blood flow: endoscopic study of effects of four large volume cuffs. BMJ 1984;288(6422):965-968.

71. Weiss M, Doell C, Koepfer N, Madjdpour C, Woitzek K, Bernet V. Rapid pressure compensation by automated cuff pressure controllers worsens sealing in tracheal tubes. Br J Anaesth 2009;102(2): 273-278.

72. Dave MH, Spielmann N, Mauch J, Weiss M. Effect of Lanz pressure regulating valve on self-sealing mechanism and air leakage across the tracheal tube cuffs in a benchtop model. J Intensive Care Med 2013;28(4):247-251.

73. Kamen JM, Wilkinson CJ. A new low-pressure cuff for endotracheal tubes. Anesthesiology 1971;34(5):482-485.

74. McCormack J, Purdy R. Airway complication related to an electromyography tracheal tube. Paediatr Anaesth 2008;18(6):572-573.

75. Abouav J, Finley TN. Self-inflating parachute cuff. A new tracheostomy and endotracheal cuff. Am J Surg 1973;125(5):657-658.

76. Abouav J, Finley TN. Prevention of tracheal injuries in prolonged ventilation. Laboratory and clinical observations on the use of selfinflating cuffs on ventilating tubes. Chest 1977;71(1):13-17.

77. Nordin U, Lyttkens L. New parachute cuff and positive end-expiratory pressure to minimize tracheal injury and prevent aspiration. Arch Otorhinolaryngol 1979;222(2):119-125.

78. Reali-Forster C, Kolobow T, Giacomini M, Hayashi T, Horiba K, Ferrans VJ. New ultrathin-walled endotracheal tube with a novel laryngeal seal design. Long-term evaluation in sheep. Anesthesiology 1996;84(1):162-172.

79. Trawöger R, Kolobow T, Cereda M, Sparacino ME. Tracheal mucus velocity remains normal in healthy sheep intubated with a new endotracheal tube with a novel laryngeal seal. Anesthesiology 1997; 86(5):1140-1144.

80. Warren DK, Shukla SJ, Olsen MA, Kollef MH, Hollenbeak CS, Cox MJ, et al. Outcomes and attributable cost of ventilator-associated pneumonia among intensive care unit patients in a suburban medical center. Crit Care Med 2003;31(5):1312-1317.

81. Safdar N, Dezfulian C, Collard HR, Saint S. Clinical and economic consequences of ventilator-associated pneumonia: a systematic review. Crit Care Med 2005;33(10):2184-2193.

82. Davis KA. Ventilator-associated pneumonia: a review. J Intensive Care Med 2006;21(4):211-226.

83. Restrepo MI, Anzueto A, Arroliga AC, Afessa B, Atkinson MJ, Ho $\mathrm{NJ}$, et al. Economic burden of ventilator-associated pneumonia based on total resource utilization. Infect Control Hosp Epidemiol 2010; 31(5):509-515.

84. Kollef MH, Hamilton CW, Ernst FR. Economic impact of ventilator-associated pneumonia in a large matched cohort. Infect Control Hosp Epidemiol 2012;33(3):250-256.

85. Kollef MH. Prevention of hospital-associated pneumonia and ventilator-associated pneumonia. Crit Care Med 2004;32(6):1396-1405.

86. Pneumatikos IA, Dragoumanis CK, Bouros DE. Ventilator-associated pneumonia or endotracheal tube-associated pneumonia? An approach to the pathogenesis and prevention strategies emphasizing the importance of endotracheal tube. Anesthesiology 2009;110(3): 673-680.

87. Torres A, Gatell JM, Aznar E, el-Ebiary M, Puig de la Bellacasa J, González J, et al. Re-intubation increases the risk of nosocomial pneumonia in patients needing mechanical ventilation. Am J Respir Crit Care Med 1995;152(1):137-141.

88. Rello J, Soñora R, Jubert P, Artigas A, Rué M, Vallés J. Pneumonia in intubated patients: role of respiratory airway care. Am J Respir Crit Care Med 1996;154(1):111-115.

89. Craven DE, Steger KA. Epidemiology of nosocomial pneumonia. New perspectives on an old disease. Chest 1995;108(2 Suppl):1S$16 \mathrm{~S}$.

90. Spray SB, Zuidema GD, Cameron JL. Aspiration pneumonia: incidence of aspiration with endotracheal tubes. Am J Surg 1976; 131(6):701-703.

91. Seegobin RD, van Hasselt GL. Aspiration beyond endotracheal cuffs. Can Anaesth Soc J 1986;33(Pt 1):273-279.

92. Vallés J, Artigas A, Rello J, Bonsoms N, Fontanals D, Blanch L, et al. Continuous aspiration of subglottic secretions in preventing ventilator-associated pneumonia. Ann Intern Med 1995;122(3):179186.

93. Asai T, Shingu K. Leakage of fluid around high-volume, lowpressure cuffs. A comparison of four tracheal tubes. Anaesthesia 2001;56(1):38-42.

94. Smulders K, van der Hoeven H, Weers-Pothoff I, VandenbrouckeGrauls C. A randomized clinical trial of intermittent subglottic secretion drainage in patients receiving mechanical ventilation. Chest 2002;121(3):858-862.

95. Dezfulian C, Shojania K, Collard HR, Kim HM, Matthay MA, Saint S. Subglottic secretion drainage for preventing ventilatorassociated pneumonia: a meta-analysis. Am J Med 2005;118(1):1118.

96. Inglis TJ, Millar MR, Jones JG, Robinson DA. Tracheal tube biofilm as a source of bacterial colonization of the lung. J Clin Microbiol 1989;27(9):2014-2018.

97. Gil-Perotin S, Ramirez P, Marti V, Sahuquillo JM, Gonzalez E, Calleja I, et al. Implications of endotracheal tube biofilm in ventilator-associated pneumonia response: a state of concept. Crit Care 2012;16(3):R93.

98. Deem S, Treggiari MM. New endotracheal tubes designed to prevent ventilator-associated pneumonia: do they make a difference? Respir Care 2010;55(8):1046-1055.

99. Coppadoro A, Berra L, Bigatello LM. Modifying endotracheal tubes to prevent ventilator-associated pneumonia. Curr Opin Infect Dis 2011;24(2):157-162.

100. Fernandez JF, Levine SM, Restrepo MI. Technologic advances in endotracheal tubes for prevention of ventilator-associated pneumonia. Chest 2012;142(1):231-238.

101. Pinciroli R, Mietto C, Berra L. Respiratory therapy device modifications to prevent ventilator-associated pneumonia. Curr Opin Infect Dis 2013;26(2):175-183.

102. Knowlson GT, Bassett HF. The pressures exerted on the trachea by endotracheal inflatable cuffs. Br J Anaesth 1970;42(10):834-837. 


\section{ENDOTRACHEAL TUBES}

103. Demers RR, Saklad M. Intratracheal inflatable cuffs: a review. Respir Care 1977;22(1):29-36.

104. Sultan P, Carvalho B, Rose BO, Cregg R. Endotracheal tube cuff pressure monitoring: a review of the evidence. J Perioper Pract 2011;21(11):379-386.

105. Hess DR. Tracheostomy tubes and related appliances. Respir Care 2005;50(4):497-510

106. Guyton D, Banner MJ, Kirby RR. High-volume, low-pressure cuffs. Are they always low-pressure? Chest 1991;100(4):1076-1081.

107. Guyton DC, Barlow MR, Besselievre TR. Influence of airway pressure on minimum occlusive endotracheal tube cuff pressure. Crit Care Med 1997;25(1):91-94.

108. Bernhard WN, Cottrell JE, Sivakumaran C, Patel K, Yost L, Turndorf H. Adjustment of intracuff pressure to prevent aspiration. Anesthesiology 1979;50(4):363-366

109. Valencia M, Ferrer M, Farre R, Navajas D, Badia JR, Nicolas JM, Torres A. Automatic control of tracheal tube cuff pressure in ventilated patients in semirecumbent position: a randomized trial. Crit Care Med 2007;35(6):1543-1549.

110. Nseir S, Zerimech F, Fournier C, Lubret R, Ramon P, Durocher A, Balduyck M. Continuous control of tracheal cuff pressure and microaspiration of gastric contents in critically ill patients. Am J Respir Crit Care Med 2011;184(9):1041-1047.

111. Pavlin EG, VanNimwegan D, Hornbein TF. Failure of a highcompliance low-pressure cuff to prevent aspiration. Anesthesiology 1975;42(2):216-219.

112. Dullenkopf A, Schmitz A, Frei M, Gerber AC, Weiss M. Air leakage around endotracheal tube cuffs. Eur J Anaesthesiol 2004;21(6): 448-453.

113. Dullenkopf A, Gerber A, Weiss M. Fluid leakage past tracheal tube cuffs: evaluation of the new Microcuff endotracheal tube. Intensive Care Med 2003;29(10):1849-1853.

114. Dave MH, Frotzler A, Spielmann N, Madjdpour C, Weiss M. Effect of tracheal tube cuff shape on fluid leakage across the cuff: an in vitro study. Br J Anaesth 2010;105(4):538-543.

115. Zanella A, Scaravilli V, Isgrò S, Milan M, Cressoni M, Patroniti N, et al. Fluid leakage across tracheal tube cuff, effect of different cuff material, shape, and positive expiratory pressure: a bench-top study. Intensive Care Med 2011;37(2):343-347.

116. Lorente L, Lecuona M, Jiménez A, Mora ML, Sierra A. Influence of an endotracheal tube with polyurethane cuff and subglottic secretion drainage on pneumonia. Am J Respir Crit Care Med 2007; 176(11):1079-1083.

117. Poelaert J, Depuydt P, De Wolf A, Van de Velde S, Herck I, Blot S. Polyurethane cuffed endotracheal tubes to prevent early postoperative pneumonia after cardiac surgery: a pilot study. J Thorac Cardiovasc Surg 2008;135(4):771-776.

118. Miller MA, Arndt JL, Konkle MA, Chenoweth CE, Iwashyna TJ, Flaherty KR, Hyzy RC. A polyurethane cuffed endotracheal tube is associated with decreased rates of ventilator associated pneumonia. J Crit Care 2011;26(3):280-286.

119. Bulpa P, Evrard P, Bouhon S, Schryvers F, Jamart J, Michaux I, et al. Polyurethane does not protect better than polyvinyl cuffed tracheal tubes from microaspiration. Minerva Anestesiol 2013;79(5): 498-503.

120. Zanella A, Cressoni M, Epp M, Stylianou M, Kolobow T. A double-layer tracheal tube cuff designed to prevent leakage: a benchtop study. Intensive Care Med 2008;34(6):1145-1149.

121. Pitts R, Fisher D, Sulemanji D, Kratohvil J, Jiang Y, Kacmarek R. Variables affecting leakage past endotracheal tube cuffs: a bench study. Intensive Care Med 2010;36(12):2066-2073.

122. Ouanes I, Lyazidi A, Danin PE, Rana N, Di Bari A, Abroug F, et al. Mechanical influences on fluid leakage past the tracheal cuff in a benchtop model. Intensive Care Med 2011;37:695-700.
123. Kolobow T, Cressoni M, Epp M, Corti I, Cadringher P, Zanella A. Comparison of a novel Lycra endotracheal tube cuff to standard polyvinyl chloride cuff and polyurethane cuff for fluid leak prevention. Respir Care 2011;56(8):1095-1099.

124. Shiotsuka J, Lefor AT, Sanui M, Nagata O, Horiguchi A, Sasabuchi Y. A quantitative evaluation of fluid leakage around a polyvinyl chloride tapered endotracheal tube cuff using an in-vitro model. HSR Proc Intensive Care Cardiovasc Anesth 2012;4(3):169-175.

125. Madjdpour C, Mauch J, Dave MH, Spielmann N, Weiss M. Comparison of air-sealing characteristics of tapered-vs. cylindricalshaped high-volume, low-pressure tube cuffs. Acta Anaesthesiol Scand 2012;56(2):230-235.

126. Li Bassi G, Ranzani OT, Marti JD, Giunta V, Luque N, Isetta V, et al. An in vitro study to assess determinant features associated with fluid sealing in the design of endotracheal tube cuffs and exerted tracheal pressures. Crit Care Med 2013;41(2):518-526.

127. D'Haese J, De Keukeleire T, Remory I, Van Rompaey K, Umbrain $\mathrm{V}$, Poelaert J. Assessment of intraoperative microaspiration: does a modified cuff shape improve sealing? Acta Anaesthesiol Scand 2013;57(7):873-880.

128. Bowton DL, Hite RD, Martin RS, Sherertz R. The impact of hospital-wide use of a tapered cuff endotracheal tube on ventilatorassociated pneumonia incidence. Respir Care 2013;58(10):15821587.

129. Hwang JY, Han SH, Park SH, Park SJ, Park S, Oh SH, Kim JH. Interrupting gel layer between double cuffs prevents fluid leakage past tracheal tube cuffs. Br J Anaesth 2013;111(3):496-504.

130. Mahul P, Auboyer C, Jospe R, Ros A, Guerin C, el Khouri Z, et al. Prevention of nosocomial pneumonia in intubated patients: respective role of mechanical subglottic secretions drainage and stress ulcer prophylaxis. Intensive Care Med 1992;18(1):20-25.

131. Kollef MH, Skubas NJ, Sundt TM. A randomized clinical trial of continuous aspiration of subglottic secretions in cardiac surgery patients. Chest 1999;116(5):1339-1346.

132. Bo H, He L, Qu J. [Influence of the subglottic secretion drainage on the morbidity of ventilator associated pneumonia in mechanically ventilated patients]. Zhonghua Jie He He Hu Xi Za Zhi 2000;23(8): 472-474. Article in Chinese.

133. Girou E, Buu-Hoi A, Stephan F, Novara A, Gutmann L, Safar M, Fagon JY. Airway colonisation in long-term mechanically ventilated patients. Effect of semi-recumbent position and continuous subglottic suctioning. Intensive Care Med 2004;30(2):225-233.

134. Liu SH, Yan XX, Cao SQ, An SC, Zhang LJ. [The effect of subglottic drainage on prevention of ventilator-associated lower airway infection]. Zhonghua Jie He He Hu Xi Za Zhi 2006;29(1):19-22. Article in Chinese.

135. Bouza E, Pérez MJ, Muñoz P, Rincón C, Barrio JM, Hortal J. Continuous aspiration of subglottic secretions in the prevention of ventilator-associated pneumonia in the post-operative period of major heart surgery. Chest 2008;134(5):938-946.

136. Yang CS, Qiu HB, Zhu YP, Huang YZ, Xu XT, Gao L. [Effect of continuous aspiration of subglottic secretions on the prevention of ventilator-associated pneumonia in mechanically ventilated patients: a prospective, randomized, controlled clinical trial]. Zhonghua Nei Ke Za Zhi 2008;47(8):625-629. Article in Chinese.

137. Zheng RQ, Lin H, Shao J, Chen QH, Lu NF, Yu JQ. [A clinical study of subglottic secretion drainage for prevention of ventilation associated pneumonia]. Zhongguo Wei Zhong Bing Ji Jiu Yi Xue 2008;20(6):338-340. Article in Chinese.

138. Lacherade JC, De Jonghe B, Guezennec P, Debbat K, Hayon J, Monsel A, et al. Intermittent subglottic secretion drainage and ventilator-associated pneumonia: a multicenter trial. Am J Respir Crit Care Med 2010;182(7):910-917. 


\section{ENDOTRACHEAL TUBES}

139. Muscedere J, Rewa O, McKechnie K, Jiang X, Laporta D, Heyland DK. Subglottic secretion drainage for the prevention of ventilatorassociated pneumonia: a systematic review and meta-analysis. Crit Care Med 2011;39(8):1985-1991

140. Wang F, Bo L, Tang L, Lou J, Wu Y, Chen F, et al. Subglottic secretion drainage for preventing ventilator-associated pneumonia: an updated meta-analysis of randomized controlled trials. J Trauma Acute Care Surg 2012;72(5):1276-1285.

141. Leasure AR, Stirlen J, Lu SH. Prevention of ventilator-associated pneumonia through aspiration of subglottic secretions. A systematic review and meta-analysis. Dimens Crit Care Nurs 2012;31(2): 102-117

142. Frost SA, Azeem A, Alexandrou E, Tam V, Murphy JK, Hunt L, et al. Subglottic secretion drainage for preventing ventilator associated pneumonia: a meta-analysis. Aust Crit Care 2013;26(4):180188.

143. Berra L, De Marchi L, Panigada M, Yu ZX, Baccarelli A, Kolobow T. Evaluation of continuous aspiration of subglottic secretion in an in vivo study. Crit Care Med 2004;32(10):2071-2078.

144. Dragoumanis CK, Vretzakis GI, Papaioannou VE, Didilis VN, Vogiatzaki TD, Pneumatikos IA. Investigating the failure to aspirate subglottic secretions with the Evac endotracheal tube. Anesth Analg 2007;105(4): 1083-1085.

145. Harvey RC, Miller P, Lee JA, Bowton DL, MacGregor DA. Potential mucosal injury related to continuous aspiration of subglottic secretion device. Anesthesiology 2007;107(4):666-669.

146. Gentile MA, Siobal MS. Are specialized endotracheal tubes and heat-and-moisture exchangers cost-effective in preventing ventilator associated pneumonia? Respir Care 2010;55(2):184-196; discussion 196-197.

147. Shorr AF, O'Malley PG. Continuous subglottic suctioning for the prevention of ventilator-associated pneumonia: potential economic implications. Chest 2001;119(1):228-235.

148. Hallais C, Merle V, Guitard PG, Moreau A, Josset V, Thillard D, et al. Is continuous subglottic suctioning cost-effective for the prevention of ventilator-associated pneumonia? Infect Control Hosp Epidemiol 2011;32(2):131-135.

149. Wyncoll D, Camporota L. Number needed to treat and cost-effectiveness in the prevention of ventilator-associated pneumonia. Crit Care 2012;16(3):430.

150. Kelly SD. Number needed to treat for subglottic secretion drainage technology as a ventilator-associated pneumonia prevention strategy. Crit Care 2012;16(5):446.

151. Dodek P, Keenan S, Cook D, Heyland D, Jacka M, Hand L, et al. Evidence-based clinical practice guideline for the prevention of ventilator-associated pneumonia. Ann Intern Med 2004;141(4):305313.

152. Tablan OC, Anderson LJ, Besser R, Bridges C, Hajjeh R, CDC, Healthcare Infection Control Practices Advisory Committee. Guidelines for preventing health-care-associated pneumonia, 2003: recommendations of CDC and the Healthcare Infection Control Practices Advisory Committee. MMWR Recomm Rep 2004;53(RR-3): $1-36$

153. American Thoracic Society, Infectious Diseases Society of America. Guidelines for the management of adults with hospital-acquired, ventilator-associated, and health-care-associated pneumonia. Am J Respir Crit Care Med 2005;171(4):388-416.

154. Masterton RG, Galloway A, French G, Street M, Armstrong J, Brown E, et al. Guidelines for the management of hospital-acquired pneumonia in the UK: report of the working party on hospitalacquired pneumonia of the British Society for Antimicrobial Chemotherapy. J Antimicrob Chemother 2008;62(1):5-34

155. Muscedere J, Dodek P, Keenan S, Fowler R, Cook D, Heyland D, et al. Comprehensive evidence-based clinical practice guidelines for ventilator-associated pneumonia: prevention. J Crit Care 2008; 23(1):126-137.

156. Tsai HH, Lin FC, Chang SC. Intermittent suction of oral secretions before each positional change may reduce ventilator-associated pneumonia: a pilot study. Am J Med Sci 2008;336(5):397-401.

157. Chao YF, Chen YY, Wang KW, Lee RP, Tsai H. Removal of oral secretions prior to position change can reduce the incidence of ventilator-associated pneumonia for adult ICU patients: a clinical controlled trial study. J Clin Nurs 2009;18(1):22-28.

158. Adair CG, Gorman SP, Feron BM, Byers LM, Jones DS, Goldsmith $\mathrm{CE}$, et al. Implications of endotracheal tube biofilm for ventilatorassociated pneumonia. Intensive Care Med 1999;25(10):1072-1076.

159. Costerton JW, Stewart PS, Greenberg EP. Bacterial biofilms: a common cause of persistent infections. Science 1999;284(5418): 1318-1322.

160. Leaper DJ. Silver dressings: their role in wound management. Int Wound J 2006;3(4):282-294.

161. Gabriel MM, Sawant AD, Simmons RB, Ahearn DG. Effects of silver on adherence of bacteria to urinary catheters: in vitro studies. Curr Microbiol 1995;30(1):17-22.

162. Ahearn DG, Grace DT, Jennings MJ, Borazjani RN, Boles KJ, Rose $\mathrm{LJ}$, et al. Effects of hydrogel/silver coatings on in vitro adhesion to catheters of bacteria associated with urinary tract infections. Curr Microbiol 2000;41(2):120-125.

163. Balazs DJ, Triandafillu K, Wood P, Chevolot Y, van Delden C, Harms $\mathrm{H}$, et al. Inhibition of bacterial adhesion on PVC endotracheal tubes by RF-oxygen glow discharge, sodium hydroxide and silver nitrate treatments. Biomaterials 2004;25(11):2139-2151.

164. Monteiro DR, Gorup LF, Takamiya AS, Ruvollo-Filho AC, de Camargo ER, Barbosa DB. The growing importance of materials that prevent microbial adhesion: antimicrobial effect of medical devices containing silver. Int J Antimicrob Agents 2009;34(2):103110 .

165. Olson ME, Harmon BG, Kollef MH. Siver-coated endotracheal tubes associated with reduced bacterial burden in the lungs of mechanically ventilated dogs. Chest 2002;121(3):863-870.

166. Berra L, De Marchi L, Yu ZX, Laquerriere P, Baccarelli A, Kolobow T. Endotracheal tubes coated with antiseptics decrease bacterial colonization of the ventilator circuits, lungs and endotracheal tubes. Anesthesiology 2004;100(6):1446-1456.

167. Berra L, Curto F, Li Bassi G, Laquerriere P, Pitts B, Baccarelli A, Kolobow T. Antimicrobial-coated endotracheal tubes: an experimental study. Intensive Care Med 2008;34(6):1020-1029.

168. Rello J, Kollef M, Diaz E, Sandiumenge A, del Castillo Y, Corbella $\mathrm{X}$, Zachskorn R. Reduced burden of bacterial airway colonization with a novel silver-coated endotracheal tube in a randomized multiple-center feasibility study. Crit Care Med 2006;34(11):2766-2772.

169. Li Bassi G, Berra L, Kolobow T. Silver-coated endotracheal tubes: is the bactericidal effect time limited (letter)? Crit Care Med 2007; 35(3):986; author reply 987.

170. Kollef MH, Afessa B, Anzueto A, Veremakis C, Kerr KM, Margolis BD, et al. Silver-coated endotracheal tubes and incidence of ventilator-associated pneumonia: the NASCENT randomized trial. JAMA 2008;300(7):805-813

171. Li X, Yuan Q, Wang L, Du L, Deng L. Silver-coated endotracheal tube versus non-coated endotracheal tube for preventing ventilatorassociated pneumonia among adults: a systematic review of randomized controlled trials. J Evid Based Med 2012;5(1):25-30.

172. Afessa B, Shorr AF, Anzueto AR, Craven DE, Schinner R, Kollef $\mathrm{MH}$. Association between a silver-coated endotracheal tube and reduced mortality in patients with ventilator-associated pneumonia. Chest 2010;137(5):1015-1021.

173. Shorr AF, Zilberberg MD, Kollef M. Cost-effectiveness analysis of a silver-coated endotracheal tube to reduce the incidence of venti- 


\section{ENDOTRACHEAL TUBES}

lator-associated pneumonia. Infect Control Hosp Epidemiol 2009; 30(8):759-763.

174. Gorman SP, McGovern JG, Woolfson AD, Adair CG, Jones DS. The concomitant development of poly(vinyl chloride)-related biofilm and antimicrobial resistance in relation to ventilator-associated pneumonia. Biomaterials 2001;22(20):2741-2747.

175. Jones DS, McMeel S, Adair CG, Gorman SP. Characterisation and evaluation of novel surfactant bacterial anti-adherent coatings for endotracheal tubes designed for the prevention of ventilator associated pneumonia. J Pharm Pharmacol 2003;55(1):43-52.

176. Furno F, Morley KS, Wong B, Sharp BL, Arnold PL, Howdle SM, et al. Silver nanoparticles and polymeric medical devices: a new approach to prevention of infection? J Antimicrob Chemother 2004; 54(6):1019-1024.

177. Pacheco-Fowler V, Gaonkar T, Wyer PC, Modak S. Antiseptic impregnated endotracheal tubes for the prevention of bacterial colonization. J Hosp Infect 2004;57(2):170-174.

178. Chaiban G, Hanna H, Dvorak T, Raad I. A rapid method of impregnating endotracheal tubes and urinary catheters with gendine: a novel antiseptic agent. J Antimicrob Chemother 2005;55(1):51-56.

179. Jones DS, Lorimer CP, McCoy CP, Gorman SP. Characterisation of the physicochemical, antimicrobial, and drug release properties of thermoresponsive hydrogel copolymers designed for medical device applications. J Biomed Mater Res B Appl Biomater 2008; 85(2):417-426.

180. Jones DS, Andrews GP, Caldwell DL, Lorimer C, Gorman SP, McCoy CP. Novel semi-interpenetrating hydrogel networks with enhanced mechanical properties and thermoresponsive engineered drug delivery, designed as bioactive endotracheal tube biomaterials. Eur J Pharm Biopharm 2012;82(3):563-571.

181. Loo CY, Young PM, Lee WH, Cavaliere R, Whitchurch CB, Rohanizadeh R. Superhydrophobic, nanotextured polyvinyl chloride films for delaying Pseudomonas aeruginosa attachment to intubation tubes and medical plastics. Acta Biomater 2012;8(5):18811890.
182. Kolobow T, Berra L, Li Bassi G, Curto F. Novel system for complete removal of secretions within the endotracheal tube: the Mucus Shaver. Anesthesiology 2005;102(5):1063-1065.

183. Berra L, Coppadoro A, Bittner EA, Kolobow T, Laquerriere P, Pohlmann JR, et al. A clinical assessment of the Mucus Shaver: a device to keep the endotracheal tube free from secretions. Crit Care Med 2012;40(1):119-124.

184. Berra L, Curto F, Li Bassi G, Laquerriere P, Baccarelli A, Kolobow T. Antibacterial-coated tracheal tube cleaned with Mucus Shaver: a novel method to retain long-term bactericidal activity of coated tracheal tubes. Intensive Care Med 2006;32(6):888-893.

185. Stone RH, Bricknell SS. Experience with a new device for clearing mucus from the endotracheal tube. Respir Care 2011;56(4):520-522.

186. Wilson AM, Gray DM, Thomas JG. Increases in endotracheal tube resistance are unpredictable relative to duration of intubation. Chest 2009;136(4):1006-1013.

187. Epstein SK. "Narrow" thinking about difficult weaning: don't forget the endotracheal tube. Respir Care 2012;57(12):2130-2132.

188. O'Grady NP, Murray PR, Ames N. Preventing ventilator-associated pneumonia: does the evidence support the practice? JAMA 2012; 307(23):2534-2539.

189. Al-Tawfiq JA, Abed MS. Decreasing ventilator-associated pneumonia in adult intensive care units using the Institute for Healthcare Improvement bundle. Am J Infect Control 2010;38(7):552-556.

190. Fletcher AJ, Ruffell AJ, Young PJ. The LoTrach system: its role in the prevention of ventilator-associated pneumonia. Nurs Crit Care 2008;13(5):260-268.

191. Young PJ, Pakeerathan S, Blunt MC, Subramanya S. A low-volume, low-pressure tracheal tube cuff reduces pulmonary aspiration. Crit Care Med 2006;34(3):632-639.

192. Doyle A, Santhirapala R, Crowe M, Blunt M, Young P. The pressure exerted on the tracheal wall by 2 endotracheal tube cuffs: a prospective observational bench-top, clinical and radiological study. BMC Anesthesiol 2010;10:21.

\section{Discussion}

Berkow: I have to preface this by saying I am a consultant for Teleflex, who markets a new bronchial blocker called the EZ-Blocker. It's different in its design in that it has 2 prongs at the end of the blocker with a balloon on each one. The idea is that you put it down into the carina, it goes into both bronchi, and you can inflate either one depending on which side you want to isolate. We've been trialing it at our institution, and people have been very pleased with how it's worked because you don't have to worry about getting the blocker in one side versus the other. My comment is that some of the challenges we have with VAP [ventilator-associated pneumonia] are like a lot of things we study: there's still no universal agreement about the definition of VAP. So if you put all these studies together, they define it differently. Is it white blood counts, or is it a proven culture? I think the other problem is that using VAP bundles independent of whether you use a special expensive ETT [endotracheal tube] has really done a lot to reduce VAP. I think the resistance to put these tubes in is that they are very expensive, and when you try to get budget money to buy a \$10 ETT versus a \$1 ETT, the fact that, down the road, itmay save money by preventing pneumonia doesn't help with your bottom line. So I think that's also part of the problem with "do we put those tubes in all patients or just some patients?"

Hess: One technique in a few of the studies you showed is to use a little bit higher PEEP level. By increasing the tracheal pressure, you can effectively reduce the amount of microaspiration around the cuff, and I would argue that that's good for the patient for a lot of reasons, and it doesn't cost any more money.

Haas: That's a great point. I think that figure by Zanella et al $^{1}$ drives it home; it seems that 5-10 $\mathrm{cm} \mathrm{H}_{2} \mathrm{O}$ 
PEEP prevented a fair amount of leakage in all tubes.

Davies: Just a comment about the SSD [subglottic secretion drainage] ETTs; we've tried them on several occasions. One thing I didn't hear you mention is the fact that their outer diameter is a little bigger for the same size inner diameter, which could complicate endotracheal intubation. In our institution, we don't like using them for intubations because we have to put a half-size larger OD [outer diameter] tube in, and this increases the risk for laryngeal trauma, tracheal trauma, and failed airway.

Haas: I've heard that, but to be honest, I don't have practical experience with that situation.

Branson: When you use the CAM Rescue Cath device, are you using it routinely or just as for rescue of a tube you believe shows signs of blockage?

Haas: Personally, with the CAM Rescue Cath, it's not routine at all; it's a patient whom we suspect has an increased ETT resistance, such as a patient who is having trouble weaning, or the ETT has been in for a while, and we're seeing smaller volumes on pressure ventilation than what we think should be generated for the $\Delta \mathrm{P}$ we're using. We might try it to see if it helps.

Branson: I'm interested to see what other people will say. I don't have a lot of experience with the tapered cuffs, but it seems to me that if the zone of sealing is a smaller area, then the pressure exerted on the tracheal mucosa must be higher. And has anybody ever followed any long-term impact of those tubes and tracheal damage?

Berkow: I don't think there are any studies to date because these tubes are too new. I know a lot of the compa- nies developing these tubes are looking at what's the best cuff shape and what kind of pressure is being generated. The problem is that even if you put them in pigs or in mannequins, it doesn't really simulate how it sits in a human trachea, and every human is a little bit different. Unfortunately, it's a really difficult question to answer. The other problem is that we're putting these tubes in patients who we think are going to be intubated longterm, so is it the cuff? Is it the tube itself in place that's causing the tracheal trauma? We don't really know that, either.

Branson: From the early data, ${ }^{2,3}$ during endotracheal intubation, the damage was not at the site of the cuff, but at the site of the cords with the curvature of the tube, where the majority of the granulomatous tissue appears. I'm not sure that the cuff is actually the problem; it just makes sense to me from an engineering perspective. It's like loading: if I put it all the weight on a small area versus a larger area, there's got to be more pressure for the same weight.

Haas: Right. I think at the top of the tapered cuff, it's still applying pressure, but there are also cuff folds, so fluid is leaking down to that point. But I haven't seen a study that's looked at the pressure along the length of the cuff to see if it was higher at the zone of sealing than it was above it. The zone of sealing implies a zone without folds, not necessarily the only area that is against the trachea.

Branson: Does anybody use the SSD tubes routinely in their institution?

Berkow: We do.

Hess: I think this is a good example of efficacy versus effectiveness. So you do an RCT [randomized controlled trial] and meticulously look at all the aspects of this; it reduces the VAP rate. But then, when you roll it out to the community, you get into issues where the suction port blocks off, you need to use a larger ETT, and you have more hoarseness after extubation and so forth.

Napolitano: Carl, wonderful presentation. The SSD tube is really problematic in that, when it fails, the classic teaching for the nursing staff is to go to the bedside and try to get that unclogged. Traditionally, what they do is flush it with saline, which sends more bacteria down the airway. We abandoned using them. One of the important things to remember in VAP is that even though the definition is problematic, we know that using the CDC [Centers for Disease Control and Prevention] definition nationwide, the rates are markedly reduced in all adult ICUs; they're down to $1-3 / 1,000$ ventilator days. Exceedingly low. Interestingly, the reservoir for VAP is in 3 surgical ICUs: trauma, burn, and neuro. And in neuro, it's mostly early trach, so everyone moves to early trach in neurologically impaired patients. So then the reservoir is really in the trauma and burn patients. We use the VAP bundle: head of bed elevated, SBTs [spontaneous breathing trials], try to get them extubated, early weaning trials, and chlorhexidine in the posterior pharynx. Once you do all that, still the rate is reduced from what used to be $12-15 / 1,000$ ventilator days down to $3-6 / 1,000$ ventilator days. The problem with use of the SSD tubes in trauma or burn patients is they're all intubated either prehospital or in the ED [emergency department], and they're intubated very quickly. Trying to move to an SSD ETT in that highrisk patient population becomes problematic because you might have to extubate and re-intubate. That becomes really problematic, particularly if they have pulmonary contusions, hypoxemia, are on high PEEP, or other issues that make re-intubation difficult, like the burn patient going back and forth to the OR [operating room] for 
grafting. It's just so challenging to try and figure out who to use the SSD ETT in and who to use the specialized tubes in, even if there was no difference in expense. I think the some of these studies did not control well for the other factors we know could reduce VAP; they simply examined this one strategy. It's a very challenging field to make sense of.

Hess: VAP reporting to the National Healthcare Safety Network has gone away, and it's now VAE [ventilator-associated events]. Part of the reason for that is there's some question as to whether the VAP rates have really gone down, or we've all done a much better job of manipulating the surveillance definitions. I'm not really convinced that the VAP rates have gone down. Some ICUs report a VAP rate of zero, but their antibiotic utilization rates have not changed. Maybe it's because we're doing a better job with VAP prevention strategies, or maybe not.

Ramachandran: Can I change the discussion to the NIM [nerve integrity monitor] tube? Just a couple of comments on the NIM tube, which is what we use to aid in surgery of the thyroid and parathyroid. A word of caution is that it has a very high coefficient of friction, and it's a flexible tube, so often they like to place it under direct vision using a GlideScope. When you do that, sometimes it's difficult to place because it's a big floppy tube, a very large tube. In one recent instance, we used a gum elastic bougie to intubate, and as the NIM tube was being advanced, it dragged the bougie in along with the tube, causing tracheal injury: just something to remember with these NIM tubes. Our experience with LITA [laryngotracheal instillation of topical anesthetic] tubes is also very spotty. These tubes are not meant to have leaks, but very often do have leaks when you place them. I don't know what the experience is around the table with these tubes. It's quite frustrating to place these tubes to pre- vent coughing at the end of the procedure before extubation, but they start leaking during the procedure because the holes below the cuff are in continuity with the holes above the cuff. Although you can cap the injection port, the airway pressure is enough for you to lose some air through that channel. It can be quite frustrating intraoperatively.

Blank: With regard to double-lumen endotracheal tubes: they are obviously bigger, stiffer, and more prone to cause airway injury, a phenomenon that's been pretty well documented. Most of these injuries are minor, but very serious tracheal/bronchial injuries can and have resulted. Until recently, there wasn't the equivalent of a Parker FlexTip tube for double-lumen species. I just want to mention a recent addition to the armamentarium: a doublelumen tube with a silicone endobronchial component. It's more tapered and is designed to pass more easily over an introducing device. It at least has the prospect of causing less tracheal/bronchial injury; I have not seen data on this yet, but hopefully they will be forthcoming.

Berkow: We use a lot of NIM tubes at our institution for thyroid surgery. We almost exclusively put them in via video laryngoscopy assistance, so everybody in the room can see proper placement of the NIM tube because you do have to line up the tube in just the right orientation at the vocal cords to get ideal stimulation during the case. They are also larger than standard ETTs, so we often have to downsize the tube. They do tend to cause more sore throats than a regular ETT. I just want to point out that if you look at the literature for otolaryngology surgery as far as outcome using these tubes, there are no studies to date that really show a significant difference in outcome or incidence of nerve injury with these tubes. So we're using them even though there's no evidence-based data to show it makes a difference.
Collins: I worry in general about manufacturer-driven health care products delivered to the medical community with lack of rigorous scrutiny or scientific evidence to prove efficiency or efficacy. There are no data that I can recall that show that NIM tubes offer any significant benefit. At our institution, we use them on occasion based on surgeon preference. This is just one example of technology that needs to be better studied and addressed in the literature, and I don't know if we've done a good job yet. There are so many new tools and devices that keep being developed so quickly that it's difficult for scientific scrutiny to stay ahead of technological advances driven by market opportunities.

Napolitano: We've had a couple occasions with the wire-reinforced tubes for ENT [otolaryngology] surgery where they've come to the OR with those tubes. As they awaken, they bite, and it reforms the tubes and obstructs. Should it be standard practice that those tubes come out and they be re-intubated prior to leaving the OR? Sometimes, there's a prediction that they're just going to be intubated overnight, but then we get into trouble in the middle of the night or a day or two later with airway obstruction.

Berkow: Yes, we've had more than one incident with anode tubes used by surgeon request for specific cases, and we had one provider who liked to use it with a Bullard intubation. We actually now have a policy that if you use a double-lumen tube or nonstandard ETT such as an anode tube in the OR, you have to change it before you go to the ICU setting if you're going to leave the patient intubated. Double-lumen tubes tend to get plugged up more easily, and the multiple ports are challenging for the ICU staff. So we have a policy that if you put a special tube in, you have to change it out, and that's really decreased our complication rate. 


\section{ENDOTRACHEAL TUBES}

\section{REFERENCES}

1. Zanella A, Scaravilli V, Isgrò S, Milan M, Cressoni M, Patroniti N, et al. Fluid leakage across tracheal tube cuff, effect of different cuff material, shape, and positive expiratory pressure: a bench-top study. Intensive Care Med 2011;37(2):343-347.

2. Whited RE. A study of endotracheal tube injury to the subglottis. Laryngoscope 1985; 95(10):1216-1219.

3. Whited RE. A study of post-intubation laryngeal dysfunction. Laryngoscope 1985; 95(6):727-729. 